IZA DP No. 10233

Immigrant Birthcountry Networks and Unemployment Duration: Evidence around the Great Recession

Kusum Mundra

Fernando Rios-Avila

September 2016 


\title{
Immigrant Birthcountry Networks and Unemployment Duration: Evidence around the Great Recession
}

\author{
Kusum Mundra \\ Rutgers University \\ and IZA \\ Fernando Rios-Avila \\ Levy Economics Institute
}

\section{Discussion Paper No. 10233 \\ September 2016}

\author{
IZA \\ P.O. Box 7240 \\ 53072 Bonn \\ Germany \\ Phone: +49-228-3894-0 \\ Fax: +49-228-3894-180 \\ E-mail: iza@iza.org
}

Any opinions expressed here are those of the author(s) and not those of IZA. Research published in this series may include views on policy, but the institute itself takes no institutional policy positions. The IZA research network is committed to the IZA Guiding Principles of Research Integrity.

The Institute for the Study of Labor (IZA) in Bonn is a local and virtual international research center and a place of communication between science, politics and business. IZA is an independent nonprofit organization supported by Deutsche Post Foundation. The center is associated with the University of Bonn and offers a stimulating research environment through its international network, workshops and conferences, data service, project support, research visits and doctoral program. IZA engages in (i) original and internationally competitive research in all fields of labor economics, (ii) development of policy concepts, and (iii) dissemination of research results and concepts to the interested public.

IZA Discussion Papers often represent preliminary work and are circulated to encourage discussion. Citation of such a paper should account for its provisional character. A revised version may be available directly from the author. 
IZA Discussion Paper No. 10233

September 2016

\section{ABSTRACT}

\section{Immigrant Birthcountry Networks and Unemployment Duration: Evidence around the Great Recession}

Using data from the CPS this paper examines the role of birth-country networks on immigrants' unemployment duration from 2001 to 2013. We find that networks significantly lower unemployment duration for all immigrants. Varying the effect of networks over duration categories we find that networks are more effective in lowering duration for immigrants unemployed for 1-2 months than immigrants who are unemployed for longer periods and this effect is further strengthened during the post recession period. This supports the CalvoArmengol and Jackson hypothesis which posits that longer the agent is unemployed, less effective are her social networks in job search. Our findings are robust to different specifications.

JEL Classification: J61, J64, D10

Keywords: $\quad$ social networks, immigrants, unemployment duration, Great Recession

Corresponding author:

Kusum Mundra

Department of Economics

Hill Hall 804

Rutgers University

Newark, NJ 07102

USA

E-mail: kmundra@andromeda.rutgers.edu 


\section{Introduction}

Using data from the monthly Current Population Survey (CPS) for the years 20012013 we focus on unemployment duration for immigrants in the U.S. before, during, and after the Great Recession. We aim to examine the effect of immigrant social networks on unemployment duration while controlling for detailed individual characteristics and location factors. In addition, we explore the effectiveness of immigrant networks with respect to the length of unemployment duration.

The recent Great Recession was characterized, among other things by an increase in delayed retirement (McFall, 2011) and a decline in home ownership rates (Ellen and Dastrup 2012 ; Owens and Sampson 2013). Even those who remained employed suffered losses during the recession, experiencing a decline in earnings due to lower real wages (Rios Avila and Hotchkiss, 2013) and fewer work hours(Aguiar et al. 2013). In terms of the labor market U.S. lost over 7.5 million jobs, with an unemployment rate that surpassed the $10 \%$ mark, and a rapid increase in unemployment duration (Farber and Valletta, 2015; Grusky et al. 2011). These increases in unemployment duration in combination with the extended unemployment benefits have generated a burden on the economy. According to the Congressional Budget Office, the federal budget spending on unemployment insurance benefits increased almost five times from 33 billion in 2004 to 155 billion in 2011. ${ }^{1}$. For households, increased unemployment not only lowered their income and hence their standard of living, but also reduced their chance of reintegrating back into the labor market.

Given that networks play an important role in immigrant job searches, it raises an important question of whether or not networks also lower their unemployment duration. This question is particularly important around an economic crisis such as the Great Recession. Recent research have shown that immigrants in the U.S. were impacted differently than natives during and after the Great Recession (Liu and Edwards 2015; Mundra and Uwaifo-Oyelere 2013). One possible factor proposed for this differential effect for immigrants versus natives is the role of immigrant social networks.

\footnotetext{
${ }^{1}$ see https://www.cbo.gov/publication/44041
} 
There is a bulk of evidence demonstrating that social networks improve ethnic minorities and migrants' labor market outcomes particularly through job referrals (Granovetter 1995; Lin 1999; Munshi 2003; Mouw 2003; Amuedo-Dorantes and Mundra 2005, Patel and Vella 2013 to name a few). In contrast, little is known regarding how networks affect immigrant unemployment duration, with only a few studies making assessments on this effect in a general employment status framework (Bentolila et al. 2010; Cingano and Rosolia 2012; Pattachini and Zenou 2012; Uhlendorff and Zimmerman 2014; Hansen 2000). There is no study exploring the effect of immigrant social networks on their unemployment duration for the U.S. and more so at the time of an economic crisis.

This paper makes three important contributions. First, to the literature on the effect of immigrant networks on labor market outcomes. This paper will shed light on whether immigrant social networks are effective in lowering unemployment duration. While the immigration literature has demonstarted that immigrants rely heavily on their social networks to improve their labor market outcomes and assimilation success, no empirical research focusses specifically on the role of immigrants' social networks on unemployment duration. We will also explore if there is a duration dependence component by looking how the effect of networks on duration of unemployment varies with the length of the time immigrants have been unemployed.

The second contribution this paper makes is to highlight the labor market dynamics and consequences of the Great Recession. Recent papers examining the impact of the recession on the immigrant population have highlighted that immigrants have been less adversely affected compared to natives by the recession in their housing outcomes due to the role of their social capital (Painter and Yu 2014; Mundra and Uwaifo-Oyelere 2013) and on their labor market outcomes due to their mobility (Liu and Edwards 2015). This paper will analyze changes in the role of networks through the Great Recession. This research is very timely and will help us answer questions on how immigrant groups fared in the recent U.S. labor market in the face of a national economic crisis. In addition, given the severity of the Great Recession and its impact on financial losses at all levels in the economy, it is important to understand whether networks reduce unemployment 
duration and hence helps lower the fiscal burden of unemployment insurance.

Third, an important aspect of this research is the identification of social networks. While networks can be theoretically identified in different ways, an operationalized measure in empirical work is difficult to obtain. We make use of the immigrants background to identify their potential networks within a specific geographical area. In this paper we use birth country networks (share of people born in the same country and living in the same state) as our network variable. We provide detail robustness of our findings including measuring networks from data sources other than CPS, such as the Census and American Community Survey (ACS). Our results using state level networks are robust to measuring networks at the local MSA level.

We use a national sample of novel monthly data on unemployed immigrants from the CPS for the years 2001 to 2013 and follow the econometric approach proposed by Güell and $\mathrm{Hu}$ (2006)-GH for the analysis of unemployment duration using repeated cross section data with uncompleted spells. The GH approach relies on the assumption that the sample is drawn from the same population across time, and enables direct estimation of the effect of networks on unemployment duration while accounting for detailed individual characteristics, local economic conditions and potential duration dependence factors.

A preview of our results suggest that networks, measured as a share of compatriots in your state, have a significant role in immigrants labor market adjustment and helps them in lowering the length of the time they are unemployed. This shows that having a larger networks helps immigrants improve their labor market opportunities and potentially increases their household welfare as well as lower the fiscal burden on unemployment insurance.

Our findings, however, also show that the quality of networks must be taken into consideration to assess how effective social networks are in influencing immigrant unemployment duration. We find that longer the immigrants are unemployed less effective are their networks in lowering their unemployment duration. This supports Calvo-Jackson theoretical hypothesis that the longer the agent is unemployed her networks consists of 
more unemployed people and hence its less effective in her job search. From our empirical model we find that networks are significantly more effective in bringing immigrants out of unemployment if they are unemployed over 1-2 months and this effect is further strengthened after the recession. During the recession with a national or global slowdown quality of immigrants networks plays a more significant role in the labor market than the pre recession period. This finding is robust to the use of Bartil IV estimation, measuring birthcountry networks from other sources of the data and other specifications.

This paper using a national large sample of immigrants with time and cross section variation and using a novel econometric approach contributes to better understanding of networks for immigrant labor market, particularly during an economic crisis but also generalizes the importance of the impact of the quality of immigrants networks on their labor market outcomes.

The rest of the paper is organized as follows. Section 2 discusses prior research on immigrant social networks and unemployment duration in detail and why immigrant networks may have a differential impact on unemployment duration around the Great Recession. In Section 3 we discuss our sample, construction of main variables and preliminary descriptive statistics. Section 4 presents our GH econometric approach and our empirical specification. Section 5 presents the discussion of our results and section 6 gives detail robustness of our findings. Finally, we conclude in Section 7.

\section{Background and Conceptual Framework}

In this section we discuss why immigrant social networks, particularly birth country networks, may play a role in their labor market outcomes such as unemployment duration

and how this role might change during the time of an economic crisis such as Great Recession. 


\subsection{Immigrants social networks and unemployment duration}

The theoretical model of Calvo-Armengol and Jackson -CJ(2004) shows that social networks have an important role for individuals in the labor market because they help to reduce job search cost by providing access to information that help in the job search process (Ioannides and Loury, 2004; Jackson, 2011). The most influential definition of social networks is provided by Granovetter $(1974,1995)$ who differentiates between weak and strong ties and finds that more than fifty percent of jobs in neighborhoods are found through contacts. Similar findings using different methods and measures of the strength of social networks is also seen in Holzer (1988), Montgomery (1991), Ionnides and Loury (2004) to name a few. For the U.S., Falcon(1995) and Falcon and Melendez (2001) show that Latinos are more likely to use individual social contacts to find jobs; Elliott (2001) also finds that newly arrived Latinos are more likely than native born Whites to take jobs through insider referrals. For the U.K., Patacchini and Zenou (2012) show that the higher residential proximity of individuals from the same ethnic group, the higher is their probability of finding jobs through social contacts. Bentolila et al.(2010) using samples from the US and Europe show that workers who found jobs using contacts show 1-2 percent lower unemployment duration but showed a significant mismatch between their productive advantage and the occupational choice. Specifically, they found that workers who used contacts to find jobs earned 2.5 percent lower wages than the others who found jobs without using their contacts.

In all these empirical papers the strength of a network is measured as a relative size of a particular population group. Higher the share of the individual's ethnic group in her neighborhood, the higher is the probability of the individual connecting with members of her ethnicity. The main caveat is that exact networks are generally difficult to identify. There are few datasets that attempt to provide a direct measure of social networks, identifying the size of the communities, friend circles or relatives that people have connections, such as Mexican Migration Project (MMP), the General Social Survey (GSS) or the DDB Needham Life Style Surveys. However, they typically do not have enough data to implement econometric analysis that concentrates on immigrants only. 
Some of the ways in which the literature has measured potential networks is whether the individual has a relative with U.S. migration experience (Orrenius 1999), the extent of individual's linguistic concentration (Chiswick and Miller 1996 ), the proportion of individuals living in the vicinity of an individual who originate from the migrants community (Munshi 2003), or a direct measure of the number of family members and acquaintances (Amuedo-Dorantes and Mundra 2007).

Social contacts with compatriots is crucial for future migration flows as well as for future labor market outcomes and assimilation of immigrants in their destination countries. ${ }^{2}$ Immigrants also settle close to their compatriots as seen by the presence of strong ethnic and immigrant gateway centers in the U.S. and for immigrants geographic proximity is closely associated with social proximity. There is a well-known, both theoretical and empirical, literature on how social networks have an important role to play in the immigrants' job search, employment and earnings. Despite the different networks measures used in the literature the common finding is that networks unambiguously increase the chances of immigrants' employment but that is not necesarily the case with earnings. ${ }^{3}$

We do not know what is the role of immigrant social networks on the immigrants unemployment duration. The literature has answered some of the questions of the heterogeneity of unemployment duration among immigrants in Europe. Uhlendorff and Zimmerman (2014), in a study for Germany, finds that migrants are more likely to experience longer unemployment duration despite staying at their jobs for similar lenghts when compared to natives with similar observable and unobservable characteristics. Christensen and Pavlopoulus (2010) find similar results for evidence from 11 European countries, but concludes that immigrants benefit more from increases on demand for low skill workers. Finally, Hansen (2000) finds that while immigrants in Sweden do experience longer

\footnotetext{
${ }^{2}$ International migration is perpetuated by the social contacts between the current migrants and nonmigrants, generating what sociologists call that "self-perpetuating" migration (Massey 1990). For a review of this literature see Massey et al. (1998).

${ }^{3}$ The literature includes a greater diversity of findings when assessing the effect of social networks on immigrants' hourly wages. Chiswick and Miller (1996) show that an increased tendency of settling in enclaves lowers English language skills among the immigrants and hence lowers their earnings; whereas, Mouw (2003) and Munshi (2003) finds that with larger networks immigrants have a higher likelihood of finding higher paying jobs.
} 
unemployment spells compared to natives, a large portion of it is explained by the differences in their demographic characteristics. The heterogeneity of unemployment duration for immigrants has not been explored for the U.S. and particulalry the role of social networks for the U.S. is missing in the literature. If networks improve the prospects of employment for the immigrants then is it also that larger networks help in lowering their eunemployment duration.

\subsection{Immigrant Networks and Duration Dependence}

There is reason to believe that the effect of networks on unemployment duration potentially depends on how long immigrants have been unemployed. According to the Calvo-Armenglo and Jackson - CJ (2004) theoretical model, the effect of networks on employment outcomes depends on the initial state of the networks and on the length the agent has been unemployed. The longer an individual is unemployed, the lower are her chances of finding jobs due to duration dependence but also the quality of networks worsens and her networks are less helpful in job searches. This might happen for two main reasons. First, in periods where unemployment is high, the longer an individual remains unemployed, the larger will be the share of unemployed migrants in her network and the larger will be the competition for the same job. Second, as the quality of the network deteriorates, network constitutes of larger number of unemployed compatriots, who do not have enough information and contacts for finding good job leads. In addition to these channels, it is also possible that individuals who have been unemployed for long periods of time have lost contact with their networks, reducing the potential effect networks have on their labor outcomes.

Cingano and Rosalia(2012) also elaborate on the quality of networks and they show that a one standard deviation increase in the network employment rate reduces the unemployment duration of a displaced worker by $8 \%$. They also find that this effect is further strengthened if the contacts searched for a job recently and if their employers are located closer to the displaced worker spatially and technologically. Their findings strengthen the hypothesis that the quality of the network is important for networks 
to be effective for immigrant labor market job searches. The longer immigrants are unemployed, the higher the chances that the immigrant network consists of less employed people making the effect of networks on job search and unemployment duration weak.

\subsection{Networks and Duration Dependence around the Great Re- cession}

The recent literature on foreclosure and loss of homeownership have shown that the Great recession has had heterogenous effects on immigrants and non-immigrants. Large proportion of minorities and immigrant households who obtained loans during the peak sub-prime period have lost their homes (Allen 2011; Mundra 2013). However, both Mundra(2013) and Kochar (2009) also find that many immigrants were less adversely affected, particularly when comparing natives and immigrants of hispanic origin. Mundra and Uwaifo Uyelere (2013) propose that part of the explanation is tied to immigrant's social capital in the U.S. and banking with ethnic banks. The very reasons that prevent the financial assimilation of immigrants might also be their insurance in the face of an economic crisis. Under financial stress, as experienced by many households in the recent financial meltdown and sub-prime crisis, immigrants may have relied on their social networks for income and financial support when the home value fell (Alsenia and Giuliano 2014).

There is also evidence suggesting that the recession had an heterogenous effect on unemployment duration across natives and immigrants. Valletta and Kuang (2012) suggest that a weak labor market is the main factor explaining the rapidly increasing unemployment duration in the recent recession and recovery in the U.S., but they do not discard the role that skill mismatching might have played in labor market dynamics.

They show that incorporating the changes in the creation of jobs does explain most of the changes observed in unemployment duration. This weakness of the labor market, however, may have had an heterogeneous effect on unemployment duration, due to the unemployment duration dependence. While the number and share of workers with less than 10 weeks of unemployment has remained relatively constant over time, the share of those with longer duration spells increased sharply during the recession, but showed a 
weaker increase after the recession.

Immigrants tend to be more vulnerable in the labor market during economic crisis. Because immigrants, particularly low-skilled immigrants, are often employed as independent contractors, and temporary help workers, they tend to be more mobile and do better during economic booms. During an economic crisis, however, they tend to be hit hardest, as sectors where they work are worsen during recessions (Liu and Kolenda 2012; Liu and Edwards 2015). This implies that immigrant job relations are very sensitive to the business cycle and labor market conditions. Orrenius and Zavodny (2009) look at the trends and cyclical fluctuations of employment and unemployment rate for immigrants and natives using the CPS data over the years 1994 - 2008. Comparing long run averages, they show that immigrants have higher employment rates and lower unemployment rates than the natives, but that is not the case when one examines the cyclical fluctuation of employment and unemployment rate.

We know that immigrants did face a tough labor market during the recession, though simultaneously the presence of some groups with higher mobility may have helped to reduce the adverse affect during the deteriorating labor market conditions. Liu and Edwards (2012), using ACS data for the years 2007 and 2009 from the 100 largest Metropolitan Statistical Areas (MSA) find that contrary to social networks arguments, during the time of economic crisis, immigrants living in MSAs with high share of immigrants actually faced tougher competition in the labor market and have worse employment prospects, particulalry female and Latino imigrants. Papademetriou and Terrazas (2009) also show similar findings for Latinos, who represent a disproportionately large group of low skilled immigrants with high school or less education and concentrated in the construction industry, which was hit tremendously during the recent recession. A couple of recent papers have shown that higher mobility among some immigrant groups have helped them in their labor market outcomes around the Great Recession (Zhu et. al. 2014; Cadena and Kovak 2016). Zhu et al. (2014) using a sample for Latino immigrants from the ACS for the years 2008 - 2010 and measuring ethnic enclaves at the PUMA level finds that 
compared to the year 2000 in the year 2010 the Latino immigrants who lived in the outer ring suburbs showed a higher likelihood of working but with a longer commute. In the face of this evidence it is important to examine how immigrants leveraged their social networks for labor market outcomes during and post the Great Recession.

The larger the size of the immigrant network the greater is the potential pool of job information and stronger are immigrants chances of finding employment in the labor market. Immigrant network have the potential to provide an insurance against future unemployment. Even if an immigrant is employed at present, having a higher pool of potential networks works as an insurance against any future negative shock to the immigrant's labor market outcome. Given that immigrant networks are effective in job searches, immigrants might rely more on their social networks during a recession. However, networks might not be effective in job searches during the time of a national slowdown on the scale of the Great Recession. As indicated before, in periods of long economic stress with high unemployment and increasing unemployment duration, the quality of the network might decline rapidly, thereby reducing its effectiveness in the job search and hence reducing any positive effect lowering unemployment duration.

\section{Data}

The data used in this paper is constructed from the monthly Current Population Survey (CPS) obtained from Integrated Public Use Microdata Series (IPUMS) for the years $2001-2013$. Given that the focus of this paper is to analyze network effects on immigrant workers, we restrict the sample to people who were born in a foreign country, excluding those born to American parents. We also restrict the sample to unemployed immigrants who are between 20 to 64 years of age in order to capture the core of the labor force among immigrants.

Unemployed immigrant workers are identified using self-reported unemployment status based on their activities during the week previous to the interview. For those 
individuals who were identified as unemployed but report to have been actively looking for a job in the last four weeks, an additional question was asked to indicate how many consecutive weeks that individual has been without a job but looking for work. This information is used to calculate the number of weeks of continous unemployment at any given time.

The years selected for analysis were chosen to obtain a panorama of the changes in labor market dynamics, specifically changes in unemployment duration before, during and after the Great Recession. In order to measure the differential impact of the migrant networks across these events, we identify three periods in our sample based on the National Bureau of Economic Research (NBER) definitions. The Great Recession is defined as the period between December 2007 to June 2009, the pre-recession covers the period from January 2001 to November 2007, and the post-recession covers the period from July 2009 to December 2013.

In addition to the standard demographic controls for sex, race, age and education, we control for citizenship, time since migration and availability of unemployment insurance. To measure the health of the labor market we use the share of employed migrants and non migrants between 20 to 64 years old for various education levels for each state, year and month.

\subsection{Measuring Networks}

As indicated before our network measure is based on a concentration index that captures the population share of immigrants at the state level who originated from the same birth country. This measure is similar to the approaches used in Munshi (2003) and Mundra and Uwaifo-Oyelere (2013). ${ }^{4}$ Specifically, for each immigrant its networks is measured as the share of population who migrated from the immigrant's birth country living in the same state during the previous calendar year. Thus for an immigrant surveyed in February of 2005 her network is measured using information from January

\footnotetext{
${ }^{4}$ Past research, as already mentioned in the literature, suggest that networks with compatriots are the most crucial for immigrants. This is also demonstrated from the trade literature, see Rauch and Trindade (2002) and Head and Ries(1998) to name a few.
} 
2004 to January 2005. The network measures are estimated using the total employed and non-employed population 15 years or older but excludes individuals born abroad to American parents.

There are several reason why an immigrant's network is the strongest with other immigrants groups from their birth country. They are more likely to share the same language, norms and culture. Moreover, these group of individuals share the same institutional background and are more likely to have similar preferences with respect to music, food, religious beliefs and same places of worship and socialization. These factors all create different reasons for interaction and connection. Moreover, solidarity or allegiance with country of birth may also incentivize immigrants to connect with birth country compatriots and also create an obligation to see them succeed which could facilitate mutual insurance. In terms of affinity, cultural identification and trust among immigrant groups, the literature has shown that immigrants form networks and share labor market opportunities the strongest with compatriots rather than with migrants from other countries (Pattachini and Zenou 2012). Given Granovetter (1995) and Amuedo-Dorantes and Mundra (2007), this notion of networks might possess more job search information and have a stronger effect on workers employment outcomes compared to networks identified only with relatives and friends.

In the framework of this paper, there are many arguments that justify the use of a state level network variable. Cadena and Kovak (2016) find that Mexican immigrants who are proportionately more low skilled were more mobile across MSAs. Given that immigrants are no longer restricted to gateway enclaves and are moving to suburbs with increasing decentralized residential patterns, measuring networks in terms of the share of state population from your birth country is a more relevant measure of networks. This is particularly relevant at the time of an economic crisis, such as the Great Recession, given that record high unemployment rates and a weak labor market might have created more competition for similar type of jobs and occupations among immigrants in small geographical areas. This competitive effect, however, might not be captured by a network variable if it is measured using a larger geographical definition and is based on a weak 
ties network definition.

Measuring networks at the state level is also beneficial if immigrants move within a state in response to the local labor market shocks. Even if the overall share of unemployed workers within the networks increases, immigrants will be more willing to share job information with compatriots over a larger geography such as a state if they tend to be less mobile within the state. Thus, during an economic crisis such as the Great Recession there are reasons to believe that networks will potentilaly be more effective at a state level rather than restricting to the local areas. While our main results are based on measuring networks at the state level, we provide robustness checks using MSA level network measure.

In empirical studies there is an important problem of identifying the causal effect of networks on labor outcome. Over and above potential omitted variable bias there is a reverse causality; immigrants have higher networks in a locality because they have better labor market or the labor market outcomes are better because of higher networks. Measuring networks as the share of the population at the state level instead of using a local geographic area mitigates this problem. We also test our results by using a Bartik type of instrument in order to obtain a measure of immigrant networks that is exogenous to changes in local market economic conditions. We discuss this in detail in Section 6.

\subsection{Descriptive Statistics}

Figures 1 and 2 provide an overall assessment of the trends on unemployment rates and unemployment duration across natives and immigrants. Both unemployment duration and unemployment rates exhibit very similar trends over time and a significant rise during the recent recession. Figure 3 shows weeks unemployed over time for three groups of networks: large networks $(2.573 \%-15.52 \%)$, medium networks $(0.394 \%-2.573 \%)$ and small networks $(0 \%-0.394 \%)$. Interestingly, we do see that immigrants with large birth country networks show lower unemployment duration than immigrants small to medium sized networks. This holds true for both during the boom and bust. ${ }^{5}$

\footnotetext{
${ }^{5}$ Immigrants from one country can be in large networks in one state and in middle or low in the other. This also changes across time. Countries within the largest networks include Mexico, Philippines, Cuba,
} 
In Table 1, we present summary statistics for the full sample of immigrants and for immigrants across the recession period. There are significant differences among the unemployed immigrants before and post the recession. We observe that average duration spell increased from almost 18 weeks before recession to almost 35 weeks after the recession. Another important change observed across different time periods is the number of weeks of insurance available to eligible unemployed workers. Starting from 18.2 week of allowance in the pre-recession period, it increased to 19.9 weeks by the time of the recession and reached more than 35 weeks in the post recession period. As described in Farber and Valletta (2015), while the increase in unemployment insurance benefits was a response to the increase in unemployment duration, these extensions could have caused part of the increases in the unemployment spell.

The CPS estimates of the potential immigrant networks seems to be robust when compared to the American Community Survey and the Census estimates (albeit smaller in 1990). There seems to be small changes in the size of networks across time periods. While there is a clear increase in immigrant network size between the pre-recession and the recession period, ${ }^{6}$ there seems to be a decline through the post recession period, as identified in Passel et al (2013).

An interesting development in the shape of the characteristics is in terms of the share of "recent" unemployed immigrants. While overall about $14.1 \%$ of the people in sample are recent migrants in the sample, there was a sharp increase in the share of recent migrants among the unemployed from $4.9 \%$ to $17 \%$ before and during the recession. By contrast the share increased by only 3 additional percentage points in the post-recession period. We also find that the share of citizens has also increased during the post recession period. As expected, during the Great Recession with slow and jobless recovery during the post recession period, recent migrants tend to be more vulnerable to fluctuations in the labor market. Citizens on the other hand tend to be more settled and less mobile and possibly show longer unemployment duration during and post the recession.

El Salvador, Dominican Republic, India, Japan, China and Portugal.

${ }^{6}$ See http://www.migrationpolicy.org/programs/data-hub/charts/immigrant-population-over-time 


\section{Econometric Approach}

In order to analyze the impact of networks on unemployment duration, we implement the Maximum Likelihood alternative of the model proposed in G'uel and $\mathrm{Hu}$ (2006). For the model to be implemented appropriateely, data across years must be representative of the same population. This methodology allows us to implement a duration analysis using cross-section data while taking into account the presence of time dependence component and uncompleted events. Implementation of the model also requires data on unemployement duration to be equally spaced, allowing us to create unemployment duration cohorts, which is key for the identification of the model. In the CPS, unemployment duration is measured in continuous weeks of unemployment, which provides enough flexibility to apply different unemployment duration cohorts for the analysis.

This estimator is implemented by arranging separate base and continuation samples across the full range of duration intervals, referred to as duration classes. For example, the individuals unemployed for 0 to 4 weeks in month t- 1 are paired with those unemployed for 5-8 weeks in month t, 5 to 8 weeks in t- 1 paired with 9-12 weeks in month $\mathrm{t}$ and so on. Based on the GH approach, the distribution of characteristics between the base sample and the continuation sample are compared and the differences in their distribution are used to infer the risk of an observation to remain unemployed, thus experiencing a longer unemployment spell. The duration dependence in the model is identified by using dummy variables that identify each unemployment cohort and estimating how that cohort relates to the probability of remaining in the unemployed sample.

For all other socio-demographic characteristics, their impact on unemployment duration is identified by comparing sample characteristics between the base and the continuation sample. For example, if immigrants in the continuation sample have lower levels of birth country networks on an average compared to immigrants in the base sample, then the regression estimates will indicate that unemployment duration declines with the immigrant birth country networks. For simplicity, on the lines of Valletta, we assume that these covariate effects are uniform across duration classes. So the estimated covariate 
effects are the average effect of the observed covariate effect across the complete set of duration pairings.

The GH-MLE model formally involves $y$ an indicator whether an individual defined by characteristics $X$ remains unemployed between consecutive months $t=0$ (base) and $t=1$ (continuation). We are interested in estimation of the conditional distribution of $y$ given $X, P(y=1 \mid X)$. In other words the estimator pools two unemployed samples in period $t$ and $t+1$. So pooling samples of individuals with duration $s$ at time $t$ and duration $s+1$ at time $t+1$ one can write down the probability that an observation belongs to the second sample conditional on $X$. Let $m_{0}$ and $m_{1}$ be the number of observations of the base and the continuation sample. We do not observe $y$ but we observe $\widetilde{y}$, which is an indicator that takes value 1 when an observation belongs to the continuation sample and 0 if it belongs to the base sample. The joint distribution of $(X, \widetilde{y})$ in the combined sample is

$$
\begin{aligned}
P(X=x, \widetilde{y}=1) & =\frac{m_{1}}{\left(m_{0}+m_{1}\right)} P(X=x \mid y=1) \\
& =\frac{m_{1}}{\left(m_{0}+m_{1}\right)} \frac{P(|y=1| X=x) P(X=x)}{P(y=1)}
\end{aligned}
$$

and

$$
P(X=x, \widetilde{y}=0)=\frac{m_{0}}{\left(m_{0}+m_{1}\right)} P(X=x)
$$

Applying Bayes' Rule we have

$$
P(\widetilde{y}=1 \mid X=x)=\frac{P(X=x, \widetilde{y}=1)}{P(X=x)}=\frac{P(X=x, \widetilde{y}=1)}{P(X=x, \widetilde{y}=0)+P(X=x, \widetilde{y}=1)}(2)
$$

$U \operatorname{sing}(1)$

$$
=\frac{1}{1+\frac{m_{0} P(y=1)}{m_{1} P(y=1 \mid X=x)}}=\frac{1}{1+\alpha \frac{1}{P(y=1 \mid X=x)}}
$$

where $\alpha=\left(m_{\left.0 / m_{1}\right)} P(y=1)\right.$. Assuming logit specification for $P(y=1 \mid X=x)$ equation (1) can be rewritten as

$$
P(\widetilde{y}=1 \mid X=x)=\frac{1}{1+\alpha \frac{1+\exp (x \beta)}{\exp (x \beta)}}=\frac{\exp (x \beta)}{\alpha+(1+\alpha) \exp (x \beta)}
$$


Equation (3) is a modified logit equation for observing whether a particular observation is in the base or continuation sample with the scaling factor $\alpha$ included. MLE estimation of (3) yields estimation of $(\alpha, \beta)$. It is important to clarify that the GH-MLE estimator is valid under the assumption that the members of the base and the continuation groups are sampled from the same population, which is the case for our monthly stratified cross sectional sampling in the CPS. This holds in the GH method for observed characteristics of the population (such as age, education, networks measure etc.) but does not hold for the unobserved individual heterogeneity in the model.

One potential problem with the information on unemployment duration captured in the CPS is the tendency of respondents to report duration, which is measured in weeks, as multiples of one month or half a year. In order to account for this "digit preference problem", we follow Valleta (2013) by randomly adding an additional week to the total numbers of continuous weeks of unemployment to $50 \%$ of the respondents that declared to be unemployed for $4,8,12,16,20,26,30,39,43,52,56$, and 78 weeks. In addition, our base and continuation groups are defined to match the duration intervals by using the following 6 unequally spaced duration intervals :

First duration interval: $5-8$ weeks in months $t$ to less than 5 weeks in $(t-1)$ second: 9-12 weeks in months $t$ to 5-8 weeks in $(t-1)$ third: $13-16$ weeks in month $t$ to 9-12 weeks in $(t-1)$ fourth: $27-39$ weeks in $t$ to $13-26$ weeks in $(t-3)$ fifth: $53-78$ weeks in month $t$ to 27-52 weeks in $(t-6)$ sixth: $105+$ weeks in month $t$ to 53-104 weeks in $(t-12)$

These are our baseline unemployment duration categories and represent the sample unemployment duration distribution effectively. Figure A in the Appendix gives the distribution of the weeks unemployed. Almost 25\% of the sample have been unemployed for less than 5 weeks, almost $24 \%$ is unemployed for 5 - 12 weeks, $24 \%$ has been unemployed between 13 - 52 weeks and $14 \%$ has been unemployed greater than 52 weeks. Since by construction the same individuals can be part of the base sample and the continuation sample, we cluster the standard errors of the model at the individual level.

It is important to mention a caveat to our findings that we are able to analyze transitions out of unemployment, but we do not know if those transitions are into em- 
ployment or out of the labor force. As it will be observed in the results, individuals with the longest levels of unemployment duration have smaller probabilities to remain in the unemployed data. Some of these immigrants might become discouraged and transition out of the labor force rather than into employment.

\subsection{Model Specification}

In equation (3) $X$ is a matrix that includes the full set of individual characteristics and state level factors. We also include a recession dummy (Recession) for months Dec 2007 - June 2009 and post recession dummy PostRecession for July 2009 - Dec 2013. Our key variable of interest is (Network) in $X$ and we interact it with the two recession dummies. The coefficient on the two interaction terms of network and recession periods, Network $*$ Recession and Network $*$ PostRecession, indicates the difference in the conditional unemployment duration of immigrants during a recession and post recession period compared to the pre recession period. If networks are relied upon more during an economic crisis, particularly at the state level, these coefficients will be positive and statistically significant.

To test the CJ hypothesis and determine whether there are any differential impacts of networks based on unemployment duration, we interact Network and Recession dummies with the unemployment duration categories to examine whether the effectiveness of networks in lowering unemployment duration depends on how long the immigrant has been unemployed. We expected that when immigrants are unemployed for longer time, networks will be of poorer quality and less effective in lowering unemployment duration.

At the individual level we control for marital status, age, whether the immigrant is female and head of the household. Immigrants with different skill levels face different labor demand and supply and also cope with unemployment differently and hence we control for different skill levels based on educational attainment: low skill (less than high school), middle skill (high school and some college), and high skill (college and graduate school). To account for the health of the skill specific labor market health we control for 
the share of employed workers at the state and each skill level. We might expect that immigrants living in states with a healthy labor market would experience shorter unemployment spells. In order to incorporate the possibility that people are extending their unemployment spells because they are relying upon unemployment benefits, we control for the maximum number of weeks people can potentially benefit with unemployment insurance at the state level (Farber and Valletta 2015). ${ }^{7}$

Since there are arguments indicating that homeowners are less mobile and more attached to the local labor market and hence face higher unemployment duration particularly during an economic downturn (Blanchflower and Oswald 2013) ${ }^{8}$, we include a homeownership dummy to control for this potential effect.

Years since immigration and citizenship are not only crucial factor for immigrants assimilation into the U.S. economy but also determine how vulnerable immigrants are in the labor market, particularly in the face of an economic crisis. These factors are also important determinants of what type of financial insurance such as savings and assets, as well as social capital, immigrants have to fall back on for their financial and labor market outcomes. We control for whether the immigrant has been in the U.S less than 10 years or not (RecentMigrant) and whether or not the immigrant is a naturalized citizen.

When discussing labor market outcomes across states for immigrants during and post the Great Recession one cannot ignore the E-Verify policies that were in place in some states. In order to address the rapidily increasing influx of undocumented immigration in the country some states passed employment verification laws to protect native and legal immigrants employment against undocumented immigrants particularly for the unskilled group. ${ }^{9}$ To control for the differences and changes across time regarding employment of immigrants and market regulations, we introduce as one of our controls an Everify

\footnotetext{
${ }^{7}$ We thank Robert Valletta for sharing this data with us.

${ }^{8}$ Though, in their empirical model they do not find any evidence to support this hypothesis.

${ }^{9}$ Studying the impact of 2007 Legal Arizona Workers Act (LAWA), the first Everify law to be passed, Bohn et al.(2014) show that in response to this Government policy there was a substantial decrease in the state's unauthorized population. They also that show that contrary to expectation LAWA failed to improve the labor market outcome of legal low-skilled workers who compete with undocumented immigrants in the state. Focusing on the Mexican population, Orrenius and Zavodny (2015) show that employment increased for Mexican legal men in states that adopted E-Verify policy
} 
variable that takes the value of zero if there is a partial implementation of the initiative, two if there is a full implementation, and 3 if the state implemented a policy similar to Everify. In regions where Everify was implemented, we might expect that it would be harder for immigrant workers, particularly undocumented immigrants, to find a job and end their unemployment. In order to account for additional time invariant effects across states, and seasonality of the data, we also control for urban labor market differences (metro dummy), state and month dummies.

\section{$5 \quad$ Discussion of Results}

Table 2 displays the results from different empirical specifications of equation (2) estimated using the GH model. The coefficient represents each variable's estimated relationship with the unemployment continuation rates of the immigrant. A positive coefficient indicates that larger variable magnitudes are associated with higher probability of unemployment continuation rates and hence longer unemployment duration whereas negative coefficient indicate the opposite.

Column 1 includes only social network and the recession/post-recession dummies. As expected, the results suggest that unemployment spells are longer after the recession, particularly during the recession period. In Column 2 we introduce controls for the unemployment duration time dependence under the hypothesis that the probability of leaving unemployment is dependent on the length of the unemployment duration. While introducing this control has little effect on the magnitude of the estimated impact of network on unemployment duration, the post-recession dummy coefficient is larger than the recession dummy coefficient and both are statistically significant. Estimating the impact of the duration categories we find that the immigrant unemployment duration shows evidence of duration dependence. Compared to the base line (from less than 4 weeks unemployed to 5 weeks unemployed) we find that duration increases for shorter spells of unemployment duration and then decreases for longer durations of 13 weeks and

higher. All coefficients are significant at one percent. Estimates for duration dependence are comparable to those found in Farber and Valletta (2015) except for long term unem- 
ployment. This might be because immigrants who are unemployed for long periods are possibly getting discouraged, which in this framework implies immigrants may leave the labor force after being unemployed for more than 2 years.

In Column 3 we test the heterogeneity of the network effect across the recession periods by introducing interactions between social networks and the recession/postrecession dummies. We find that during and after the Great Recession compared to the pre recession period, networks have no additional effect on unemployment duration. One possible interpretation for this finding is that having a higher share of compatriots and hence a larger pool of job market information helps lower unemployment continuation rates and hence shortens unemployment duration. There is no additional benefit of higher networks on lowering unemployment duration during the recession and post recession period compared to the pre-recession period. Nevertheless, it should be noted that we estimate a positive additional effect during the recession and a negative effect after the recession.

As described elsewhere in the literature individual demographic characteristics, labor market experience, and household characteristics can have an impact on immigrant employability and thus on the length of unemployment duration. In column 4 we account for these factors and find that the effect of network on duration is still strong and significant. However, the estimate on the additional impact during the recession is now almost zero. Regarding each additional estimate, we find evidence of a $U$ shape relationship between unemployment duration and age, and that women are more likely to remain unemployed from one period to the next, which is consistent with Abraham and Shimer (2002) and Valletta (2013). We also find that immigrants with at least a high school diploma are more likely to remain unemployed for longer periods. This is possibly correlated with the fact that high-skilled workers tend to face steeper job search costs and higher market frictions compared to low-skilled workers, and might be more likely to remain unemployed until the "right" job appears. We also find that household size, number of children, being a head of the household (or spouse) and race are not related to the length of unemployment duration. 
Similar to the findings in the earlier literature (Valleta 2013; Blanchflower and Oswald 2013) we find no evidence that being a home owner affects unemployment duration, see column 4. While one might expect that owning a home makes an individual less mobile and hence increase her unemployment due to labor market frictions, the estimates suggest that no such relationship exists. As suggested by Blanchflower and Oswald (2013), homeownership is related to lower labor mobility, which might translate into longer unemployment periods through the "house lock" effect. It is possible that we are unable to detect such effect for two reasons. First, because we do not follow households across time, and second, because in the aggregate the composition of the CPS data balances out the sample of home owners and non-homeowners.

In addition to all controls we mentioned above, in column 5 we include factors related to immigrant assimilation at the individual level and whether the state implemented Everify or not. While being a recent immigrant (ten years or less since moving to the U.S.) does not seem to be related to longer unemployment spells, becoming a U.S. citizen is. It is possible that this happens because citizens can easily participate in U.S. welfare payments, allowing immigrant workers to remain unemployed while searching for a job. Regarding employment regulations, the variables identifying the level of implementation of the E-verify have the expected sign. A more comprehensive implementation of the E-verify program increases the frictions on the hiring of immigrant workers, which explains the positive estimated relation with unemployment duration. Other types of programs that had a similar intention to E-verify, however, do not seem to be correlated with unemployment duration. Liu and Edwards (2015) describe similar results for states in which E-Verify was in place or about to be adopted immigrants had an adverse effect on their employment probabilities compared to other states. Controlling for these assimilation factors and employment regulations reduces the additional negative effect of networks after the recession, although it remains insignificant.

In our final and preferred model, given in column 6, we add as controls employment share in the state and the state level unemployment benefits. As discussed in Farber and Valleta (2015), we observe that longer unemployment benefits increases the probabil- 
ity of an immigrant remaining unemployed. In contrast, living in a healthier local labor market with high employment shares reduces the probability of staying unemployed and thus reduces unemployment duration.

It is important to emphasize that even after controlling for all individual and state level characteristics, we find that immigrants benefit from larger networks as this variable remains negatively related to longer unemployment spells. However, the evidence indicate that on average, this effect of networks does not vary from pre recession to the post. ${ }^{10}$ So having larger birth country networks does not provide any additional benefit during the recession period. Still, there is a possibility that if we take the duration dependence effect of networks there might be a differential effect of networks during and post the recession period.

\subsection{Networks and Duration Dependence}

While on average networks do not seem to have an important effect on unemployment duration, it is possible that there is some heterogeneity on the impact of networks when considering the length of unemployment duration of workers. CJ proposed a social network model where unemployment shows duration dependence for an agent and the probability of finding a job decreases the longer the agent is unemployed. In their model, the longer the individual is unemployed, the poorer is the network quality of the agent and her networks are weak on job information. In order to test the CJ hypothesis as an extension of our baseline model we include networks interacted with duration dependence categories.

Results are given in Table 3 using the full set of explanatory variables based on our final model from column 6 in Table 2. In all cases, the interactions with length of unemployment should be interpreted as an additional effect to the baseline estimations. In Column 1 we present the results using the interactions with the detailed unemployment duration categories. In columns 2 and 3 we use two alternative unemployment duration categories for robustness. In columns 1 and 3, the base line are those unemployed between

\footnotetext{
${ }^{10}$ All the results shown here hold when we restrict the data to household heads and spouses only. These results are available from the authors.
} 
1 to 4 weeks and in column 2 the base line includes those unemployed up to 8 weeks. We find that after accounting for duration dependence of unemployment networks have a differential effect before and after the recession. The estimates on the birthplace networks and its interactions indicate that workers who have been unemployed for a short time are less likely to remain unemployed the larger their networks are. Furthermore, this effect is even larger during the post recession period.

Comparing the impact of networks before the recession after accounting for duration dependence, we observe that while the point estimates are large, only those corresponding to immigrants who have been unemployed between 13-26 weeks have a statistically different impact from immigrants with their size of birthplace networks. For them, networks have been less effective in reducing probability of remaining unemployed. This is observed both in the specifications of column 1 and column 2. Turning to the effects of networks during the recession period, the specifications in columns 1, 2 and 3 suggest that compred to the baseline effect there is no statistically different impact of networks upon unemployment.

Finally, for the post-recession period we find that the effect of networks on duration not only declines, but that networks increase the probability of remaining unemployed for workers who have been unemployed for long periods of time. According to column 1 and column 2, this is seen for workers unemployed longer than 27 weeks. Column 3 suggests that this effect is also seen for those unemployed between 5 to 12 weeks, although it is significant only at $10 \%$. The data suggest that the estimated impact is larger for immigrants who have been unemployed for longer periods of time.

To put our findings into context we use the preferred model in column 1 Table 3 and estimate average probability of continuation of unemployment at different network sizes for immigrants who have been unemployed between 1 - 4 weeks and those that are unemployed for 27 - 52 weeks for the three periods. In this case we use the estimates of the preferred model and make predictions about the probability of unemployment continuation for various simulated changes in the network size. This is what we call the marginal effect of immigrant networks on the risk of continuing to be unemployed 
at various networks sizes and Figures 4 and 5 display this effect for immigrant groups who have been unemployed for 1-4 weeks and 27-52 weeks respectively. ${ }^{11}$ Figures 4 and 5 display this effect we see that higher networks are helpful in lowering unemployment duration for all periods for immigrants who have been unemployed for 1-4 weeks and that post recesion immigrants with larger birthplace networks have lower risk of continuing the unemplyment state versus immigrants with smaller network size. However, this is not the case for immigrants with 27-52 weeks of unemployment.

Overall examining whether immigrant social networks have a significant differential effect over various duration categories we find that networks are significantly more effective in lowering unemployment duration over 1- 2 months of unemployment duration, and this effect increased after the recession. However, networks are ineffective when immigrants have been unemployed for a longer time. This supports the CJ hypothesis that immigrants in the U.S. who are unemployed for a longer duration have lower quality networks with poor new job information and their networks are not as effective as that of immigrants with shorter unemployment duration. It is also possible that after the Great Recession, a period where unemployment continued to increase, networks are measuring increasing competition in the labor market among compatriots. This would explain why networks are increasing unemployment for immigrants with longer unemployment spells.

\section{Robustness of our Findings}

As described in the data section, the analysis until now has used monthly CPS data to measure immigrant networks, based on the average share of people living in any given state in the previous 12 months. We expect that using this lagged information would reduce potential endogeneity problems caused by using contemporaneous data, while allowing us to pool more data to obtain a more accurate measure of networks compared to data from a single month. At the same time we expect that state level measures are the most appropriate to capture local labor market networks. Nevertheless, it is possible to argue that this measure is not exogenous and the estimates may not be consistent,

\footnotetext{
${ }^{11}$ The average estimates are available upon request.
} 
or that using state level data is not appropriate to capture the network effects upon unemployment duration. In this section we explore various alternative measures of the birth country networks, as well as implement an instrumental variable strategy, to assess the robustness of our results.

\subsection{Measuring Networks using Census and ACS}

The first robustness test we implement in our analysis is to measure immigrants networks using Census and ACS data to test the robustness of the CPS network measures. Even when analyzing unemployment in period we calculate network using CPS data from the previous 12 months there may be a concern that due to the longitudinal component of the CPS data our measure of networks is endogenous by construction. This is possible because the same individual would be counted as part of her own network, which could create a problem for individuals with smaller networks. A possible solution to this problem is to use an external dataset to create the network measure. For this purpose we present three estimates where the network variable is measured using annual data from the ACS, and using data from the 5\% Census data for the years 1990 and 2000 in Table 4, all obtained from the IPUMS project.

First, in column 1, we present the estimates using the last year immigrants network measure based on ACS data from 2000 to 2012 data. While there is less variation in this measure, year-to-year compared to month-to-month from the CPS measure, the estimated impact of networks on unemployment duration are consistent with our main findings. The coefficients are somewhat smaller for the networks coefficient when interacted with the recession and post-recession dummies, but they show the same sign as in the preferred model and remain insignificant.

While using an external dataset such as the ACS, to estimate the network measure might alleviate possible endogeneity problems, using last year network information might not be enough to deal with a second potential type of endogeneity. Migrants will tend to move in areas with already large migrant enclaves because of a combination of labor market opportunities and social network pulls. In Columns 2 and 3, we address this 
concern by using a network measure based on data from the Census 1990 and 2000. The advantage of using Census data is that we have a more accurate measure of networks compared to the ACS or CPS estimates, and potentially more exogenous. To account for the fact that migration was less prevalent in 1990 compared to 2000 Census, network size estimate is adjusted by inflating the share of immigrants in the year 1990 to that observed in the year 2000 .

Our estimations indicate that using either networks measure provides consistent results with the benchmark. Taking into consideration that this strategy relies only upon network size variation across country of birth for identification, we find that the results based on the 2000 Census data are closer to the preferred mode, and the 1990 Census, after adjustment, are slightly smaller. Although the results regarding the recession and post recession interactions are still insignificant, it should be noted that the point estimates for the network and recession/post-recession interactions are larger compared to our benchmark.

\subsection{Bartik Type IV Aproach}

One potential problems with the identification strategy with this methodology is that the size of immigrant networks as measured by the concentration of migrants of the same country in a given state, might be endogenous due to a simultaneity problem. The reason for this is that unmeasured local market conditions can both affect the unemployment duration of workers and attract/discourage migrant workers into the state. In this case, the changes in the size of migrant networks and changes in the unemployment duration might be spuriously related.

On the other hand, the drawback of using networks measures based upon 1990 and 2000 Census data is that we lose time variation in our networks measure and the effect is only identified through variation across countries of birth. An alternative solution is to use the tendency of migrants to move to areas with already high concentration of migrants as an instrument for our networks measure, in what is commonly known as the Bartik instrument (Bartel 1989, Bartik 1991). This instrumental variable is used to 
decompose the total migration change, here change in network size, into an exogenous supply-push component (inflow of immigrants) and an endogenous component (caused by changes in the labor market conditions).

To implement this methodology, we use the most reliable estimation of network size for the year 2000, collecting data on total number of immigrants by country of origin for each state, as well as total population per state based on the Census 2000-summary file 3. To obtain the network size for the last period of our analysis, year 2013, we estimate the total number of immigrants by country of origin at the national level using the ACS- 5 year sample. The annual change in the number of immigrants is estimated using linear interpolation between the years 2000 and 2013. This change is then distributed across states using the immigrant concentration ratio observed in the 2000 Census data. Finally, the network size is estimated using the interpolated state level immigrant pool divided by the total state population of the same year, obtained from population estimates from the U.S. Census Bureau. This constitutes the Bartik instrument for our CPS networks variable.

In order to implement the IV estimator in the framework of the GH-MLE model, we apply a two-step procedure. In the first stage, we regress the constructed Bartik instrument and all the variables used in the GH model on the immigrant network measure using the CPS data in a linear model. Once the linear prediction is obtained, the GH model is estimated using the predicted network size. The process is bootstrapped to obtain the corrected standard errors in the model and the results are presented in column 5. Since the data used from the summary files has a different classification compared to the CPS data, and few countries are not identified, the results are no longer comparable to the benchmark results presented in Table 2. Instead we present estimates using a sample consistent upon with the IV-Bartik estimates which are presented in column 4 for comparison. Based upon the estimates, the Bartik consistent sample and the Bartik IV estimates are consistent with the benchmark results, although the coefficients are smaller. 


\subsection{MSA level Networks}

As mentioned earlier, we measure birth country networks at the state level because we want a measure that is not sensitive to local market conditions and we want to reduce the bias that can be caused by migrants moving for job search reasons within the same state. It is possible to argue that a measure of a more effective birthplace network should be estimated using a smaller geographical area such as county, city or MSA. There are several reasons why this method is not advisable.

First, for about $12 \%$ of the sample we does not have MSA information and many others do not live within the boundary of an MSA. In addition, since the group of interest, immigrants, is relatively small, network measures at a smaller geographical level based on CPS data will be far less accurate, and might introduce an attenuation bias to the estimates. Second, given that we are interested in groups with which immigrants can potentially connect and get help with finding jobs, it is preferable not to confine that to a county level especially since most social groups and associations that form the basis of network formation and interactions operate at the city, state or national level. Information on jobs and other labor market opportunity through co-national networks and compatriot association are shared and utilized at the state level.

Last but not the least, networks at the municipal and county level are more likely to be endogenous than networks measured at the state level. Network measures at the state level are less sensitive to migrants moving within the state. Cadena and Kovak (2016) in their recent paper show that Mexican immigrants were more mobile than natives during the recent recession and responded to the local labor market demands. They find that for low skilled workers natives living in metro areas with a high Mexicanborn population experienced a roughly $50 \%$ weaker relationship between the recession shock and the employment probabilities. If that is the case then measuring networks at the local level such as MSA will make networks more endogenous to the employment and unemployment possibilities and hence the labor market outcome of the immigrant. While migration across states exist in the data, it is less common than movement within state. For our sample of 15 and older population the migration rate across county in a state is 
9.1\% whereas across states is only $1.97 \%$.

Despite this potential drawbacks of using MSA level networks, we create a network variable using the share of immigrants at the MSA level and the results are presented in column 7 (table 4). While the network variable is still significant and has a negative effect on unemployment duration, the point estimate is less than half of the one from the benchmark model. Based upon our discussion, it is possible that the estimate is small due to attenuation bias or due to endogeneity bias, as MSA networks are not representative of people who recently moved within the state. It is also possible that the estimates are smaller because we are using a different sample that excludes individuals whose MSA cannot be identified. To account for the sample change, we reestimate the benchmark model using the state level network measure, but using the same sample as in Column 7 . Results are given in Column 8. We find that the network effect for those living in Metro areas is smaller compared to the benchmark and larger than the estimate in column 7 , but is still significant at the $1 \%$ level of significance.

\subsection{Non-Mexican Immigrants}

Mexicans are the largest group of immigrants in the U.S. and so have the largest share of birth country networks. In our sample average size of networks for Mexican immigrants is roughly ten times larger than that of non-Mexican immigrants. A last important robustness for our national sample is to show that our findings hold for nonMexican immigrants. We estimate our baseline model for Mexican immigrants and NonMexican immigrants. As expected, the effect of networks is significantly larger magnitude for Mexicans compared to Non-Mexican immigrants but it holds for both groups (see Appendix Table A).

\section{Conclusion}

This paper explores whether immigrant networks affect immigrant unemployment duration, particulalry around the Great Recession. Immigrant networks are measured at

the state level using the share of immigrants from the same country of origin and based 
on our preferred results we find that birth country networks have a significant effect on lowering the duration of unemployment. When we do not allow this network effect to vary with the length of the unemployment we find that networks have no additional role in the post recession period than the pre recession period. However, that is not the case when we allow for the role of networks to vary with the length of unemployment. This finding supports the hypothesis from the social networks theory literature that the longer the agent is unemployed, the poorer is the quality of her network in terms of labor market information and consequently networks are not helpful in job searches.

Interestingly, using different classifications of unemployment duration categories we find some evidence that networks are more effective in lowering unemployment duration for immigrants who are out of the labor force for a shorter period of time. After accounting for the heterogeneity of the effectiveness of networks across duration intervals we find that the risk of continuing to be unemployed is significantly lower for immigrants with 1-4 weeks of unemployment duration with larger network size during the post recession period than the pre recession period. This finding persisits if we use network measures from other data sources, Bartik Type IV estimation, or measure networks at the MSA level. Moreover, our findings are not driven by the outlier group of Mexican immigrants.

Using a well represented sample of immigrants in the U.S. over more than a decade this paper makes an important contribution in establishing a persistent role of networks in reducing the immigrants risk of continuing to be uenmployed at the state level. This research provides an important insight into the immigrants labor market adjudstment, particularly at the time of an economic crisis. Our results also highlight that it is crucial to account for the quality of social networks when examining the role of immigrant networks on their labor market outcomes. 


\section{References}

[1] Aguiar, M., E. Hurst and L. Karabarbounis 2013. "Time Use During the Great Recession," American Economic Review, 103(5): 1664-1696.

[2] Abraham, K., and R. Shimer. 2002. Changes in Unemployment Duration and Labor Force Attachment In The Roaring Nineties, edited by Alan Krueger and Robert Solow. New York: Russell Sage Foundation.

[3] Alesina, A. and P. Giuliano. 2014. "Family Ties" Handbook of Economic Growth, edited by Philippe Aghion and Steven N Durlauf, 2A: 177-215. The Netherlands: North Holland, 2A, 177-215.

[4] Allen R. 2011. "Who Experiences Foreclosures? The Characteristics of Households Experiencing a Foreclosure in Minneapolis/Minnesota, " Housing Studies 26(6), 845866.

[5] Amuedo-Dorantes, C. and K. Mundra 2007. Social Networks and Their Impact on the Employment and Earnings of Mexican Immigrants. Demography,44(4), 849-863.

[6] Bartel, Anne 1989. "Where do the new US immigrants Live," Journal of Labor Economics 7, pp. 371-91.

[7] Bartik, T. J. 1991. Who Benefits from State and Local Economic Development Policies? Kalamazoo MI: W. E. Upjohn Institute for Employment Research.

[8] Bentolia, S., C. Michelacci and J. Suarez 2010. "Social Contacts and Occupational Choice, "Economica 77, 20 - 45.

[9] Blanchflower, D. G. and A. J. Oswald. 2013. "Does High Home-Ownership Impair the Labor Market, "NBER Working Paper Series Working Paper 19079.

[10] Bohn, S., Lofstrom, M., and Raphael, S.2014. "Did the 2007 Legal Arizona Workers Act Reduce the State's Unauthorized Immigrant Population?," Review of Economics and Statistics, 96(2), 258â'“269. 
[11] Cadena, B. C. and B. K. Kovak. 2016. "Immigrants Equilibrate Local Labor Markets: Evidence from the Great Recession," American Economic Journal: Applied Economics, 8(1), pp. 257-290.

[12] Calvo-Armengol and M. Jackson (2004). "The Effects of Social Networks on Employment and Inequality," American Economic Review, 94(3),pp. 426-454.

[13] Chiswick, Barry R. and Miller, Paul W. 1996. "Ethnic Networks and Language Proficiency Among Immigrants, "Journal of Population Economics, 9(1), 19-35.

[14] Christensen, A. M. and D. Pavlopoulos. 2010. "Do welfare and labour market institutions influence unemployment duration of immigrants?. Evidence from 11 European countries,"Working Paper 2010-04. CEPS/INSTEAD Working Papers. Luxembourg Institute of Socio-Economic Research

[15] Cingano F. and A. Rosolia 2012, "People I Know: Job Search and Social Networks," Journal of Labor Economics, 30(2), pp. 291-332.

[16] Ellen I. G. and S. Dastrup 2012. "Housing and the Great Recession," Policy Brief, Russell Sage Foundation and the Stanford Center on Poverty and Inequality.

[17] Elliott J. R. 2001. "Referral Hiring and Ethnically Homogeneous Jobs: How Prevalent Is the Connection and for Whom?," Social Science Research, 30(3), 401-425.

[18] Falcon L. M. 1995. "Social Networks and Employment for Latinos, Blacks, and Whites," New England Journal of Public Policy,

[19] Falcon L. M. and E. Melendez 2001. "Racial and ethnic differences in job searching in urban centers in Urban inequality: Evidence from Four Cities, ed. Alice Oât ${ }^{\mathrm{TM}}$ Connor, Chris Tilly, and Lawrence Bobo. New York: Russell Sage Foundation.

[20] Farber H. and Valletta R. 2015. "Do Extended Unemployment Benefits Lengthen Unemployment Spells? Evidence from Recent Cycles in the U.S. Labor Market," Journal of Human Resources. 50(4):873-909. 
[21] Güell Maia, Hu, Luojia, 2006. "Estimating the probability of leaving unemployment using uncompleted spells from repeated cross-section data, "Journal of Econometrics 133, 307-341.

[22] Granovetter M. 1973. "The strength of weak ties, " American Journal of Sociology, 78(6):1360â" 80.

[23] Granovetter M. 1995. Getting a job: A study of contacts and careers. Chicago: University of Chicago Press.

[24] Grusky D. B. , B. Western, and Wimer C. 2011. The Great Recession, Russell Sage Foundation.

[25] Hansen J. 2000. “The Duration of Immigrants' Unemployment Spells: Evidence from Sweden," IZA Discussion Paper No. 155.

[26] Head, K., and J. Reis. 1998. Immigration and Trade Creation: Econometric Evidence from Canada, " Canadian Journal of Economics 31(1): 47-62.

[27] Holzer H. (1988). "Search method use by unemployed youth, "Journal of Labor Economics, 6, 1â'"20.

[28] Ionnides Y. M., and L. D. Loury. 2004. "Job information networks, neighborhood effects, and inequality", Journal of Economic Literature 42:1056â"93.

[29] Kochar R., A. Gonzalez-Barrera, and D. Dockterman 2009. "Through Boom and Bust: Minorities, Immigrants and Homewonership "Pew Hispanic Report.

[30] Lin N. 1999. "Social Networks and Status Attainment," Annual Review of Sociology, 467-87.

[31] Liu C. Y. and J. Edwards 2015. "Immigrant Employment through the Great Recession: Individual Characteristics and Metropolitan Contexts," Social Science Journal,94(1), 137-151.

[32] Liu C. Y. and R. Kolenda, 2012. "Counting and Understanding the Contingent Workforce," Urban Studies, 49(5), 1003-1025. 
[33] Massey, D. S. 1990. "Social Structure, Household Strategies, and the Cumulative Causation of Migration, "Population Index, 56(1), 3-26.

[34] Massey, D. S., A. Joaquin, G. Hugo, A. Kouaouci, A. Pellegrino, and J. E. Taylor 1998. Worlds in Motion: International Migration at the End of the Millennium. Oxford: Oxford University Press.

[35] McFall B. H, (2011). "Crash and Wait? The Impact of the Great Recession on the Retirement Plans of Older Americans," American Economic Review-Papers and Proceedings, 101(3), 40-44.

[36] Montgomery J. (1991). "Social networks and labor-market outcomes: toward an economic analysis text, "American Economic Review, 81, 1408â'18.

[37] Mouw T. 2003 "Social Capital and Finding a Job: Do Contact Matter?," American Sociological Review, 2003, 68(6), 868-870

[38] Munshi K. 2003. "Networks in the Modern Economy: Mexican Migrants in the U. S. Labor Market," The Quarterly Journal of Economics, 549-599.

[39] Mundra K. 2013. "Minority and Immigrant Homeownership Experience: Evidence from the 2009 American Housing Survey," IZA Discussion Paper 7131.

[40] Mundra K. and Uwaifo-Oyeler, R. 2013 . "Determinants of Immigrant Homeownership: Examining their Changing Role during the Great Recession and Beyond" IZA Working Paper.

[41] Orrenius P. M. and M. Zavodny 2009. "Tied to the Business Cycle: How Immigrants Fare in Good do and Bad Economic Times," Migration Policy Institute.

[42] Orrenius P. 1999. "The Role of Family Networks, Coyote Prices and the Rural Economy in Migration from Western Mexico: 1965-1994,"Research Department Working Paper 9910, Federal Reserve Bank of Dallas.

[43] Owens A. and R. J. Sampson. 2013. "Community Well-being and the Great Recession." Pathways Spring 3-7 Stanford, CA: Stanford Center on Poverty and Inequality. 
[44] Painter G. and Yu Z. 2014. "Caught in the Housing Bubble Immigrants' housing outcomes in traditional gateways and newly emerging destinations," Urban Studies, 51(4), 781-809.

[45] Papademetriou D. and G. and A. Terrazas 2009. "Immigrants and the Current Economic Crisis,"Washington, DC: Migration Policy Institute.

[46] Passel, J. S. and D. Cohn and A. Gonzalez-Barrera 2013. "Population Decline of Unauthorized Immigrants Stalls, May Have Reversed "Washington, DC: Pew Research Center.

[47] Patacchini E. and Y. Zenou 2012. "Ethnic Networks and Employment Outcomes," Regional Science and Urban Economics,42 :938-949.

[48] Patel, K. and F. Vella 2013. "Immigrant Networks and Their Implications for Occupational Choice and Wages," Review of Economics and Statistics, 95(4), 1249-1277.

[49] Rauch J. and Trindale, V. 2002. Ethnic Chinese Networks in International Trade," Review of Economics and Statistics 84(1), 116-130.

[50] Rios-Avila F. and J. L. Hotchkiss, 2014. "A Decade of Flat wages?"Policy Note 2014/4, Levy Economics Institute

[51] Uhlendorff A. and Zimmermann K. F. 2014. "Unemployment Dynamics Among Migrants and Natives, "Economica, 81(322), 348-367.

[52] Valletta R. G. 2013. "House Lock and Structural Unemployment," Labor Economics, $25,86-97$.

[53] Valleta R. G. and K. Kuang (2012). "Why is Unemployment Duration So Long?,"FRBSF Economic Letter.http://www.frbsf.org/economicresearch/files/el2012-03.pdf

[54] Zhu P., C. Y. Liu and Painter, G. 2014. "Does Residence in the Ethnic Community Help Immigrants in a Recession?," Regional Science and Urban Economics, 47, 112 127. 


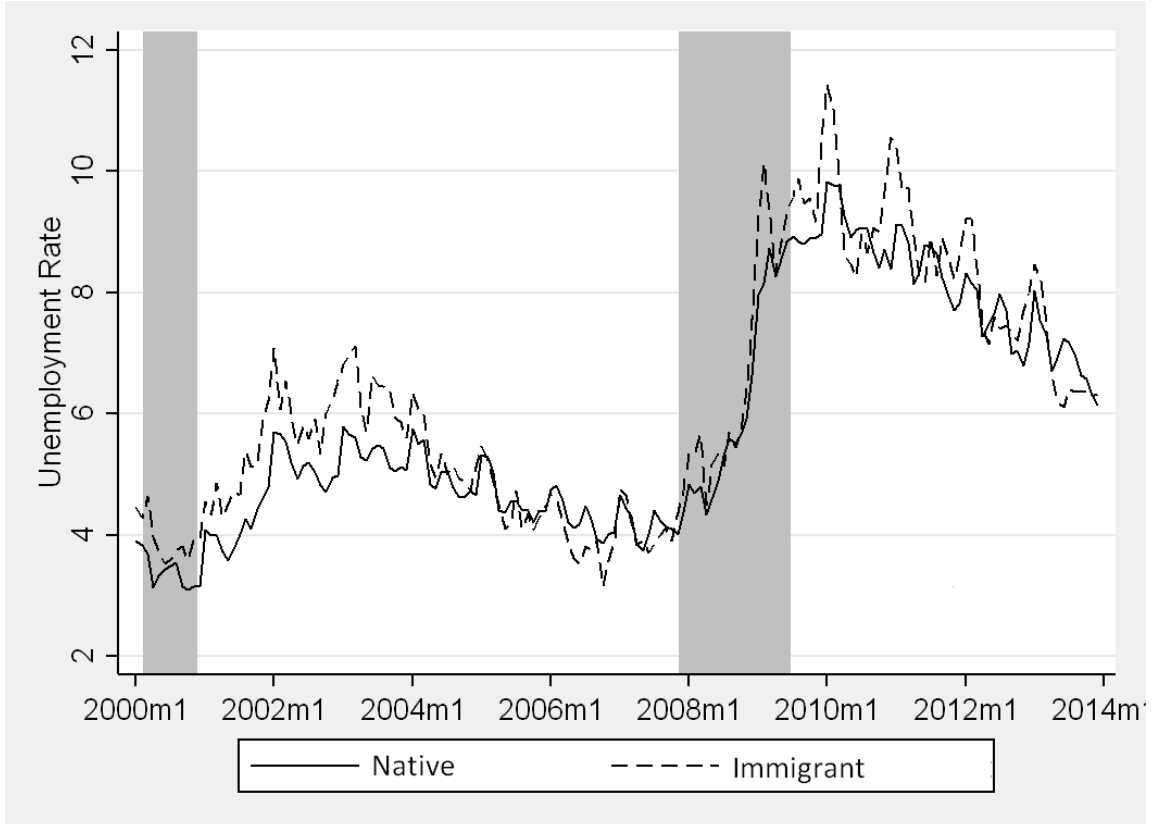

Figure 1: Unemployment Rate Monthly Trend for Immigrants and Natives over 2000 2013 


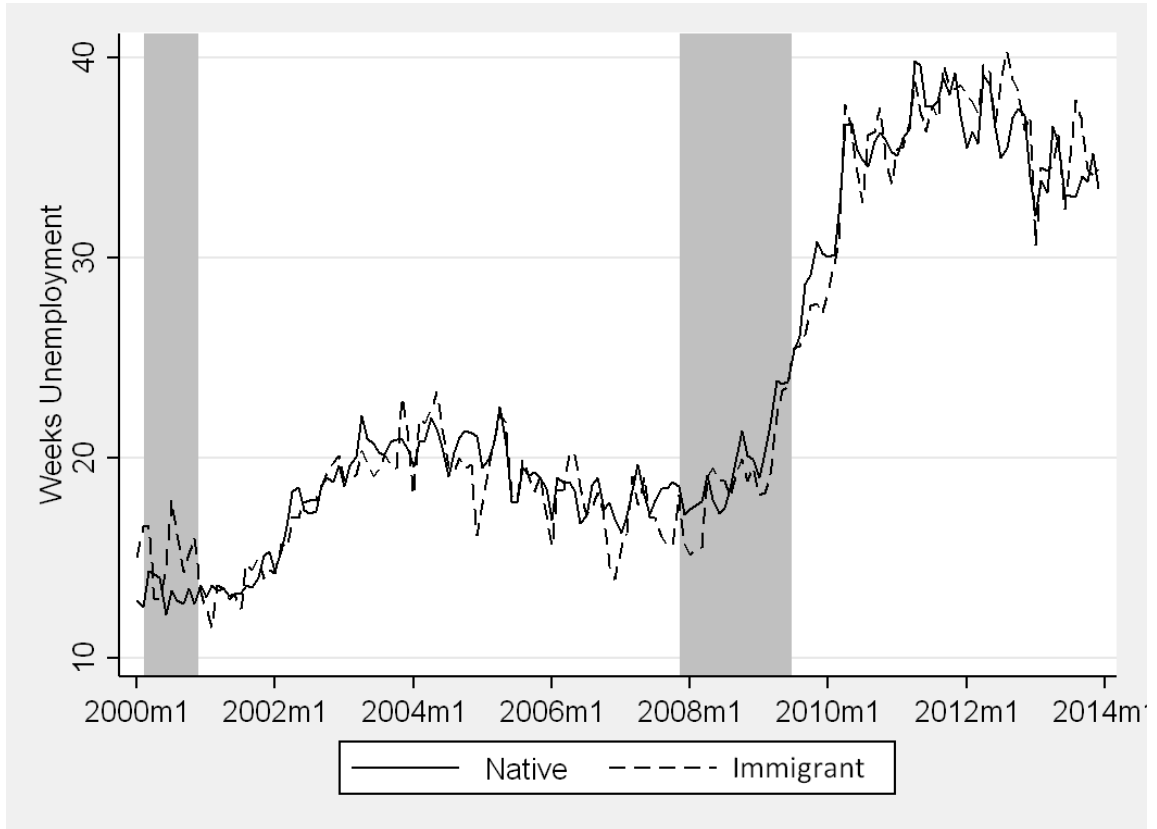

Figure 2: Unemployment Duration Monthly Trend for Immigrants and Natives over 2000 $-2013$ 


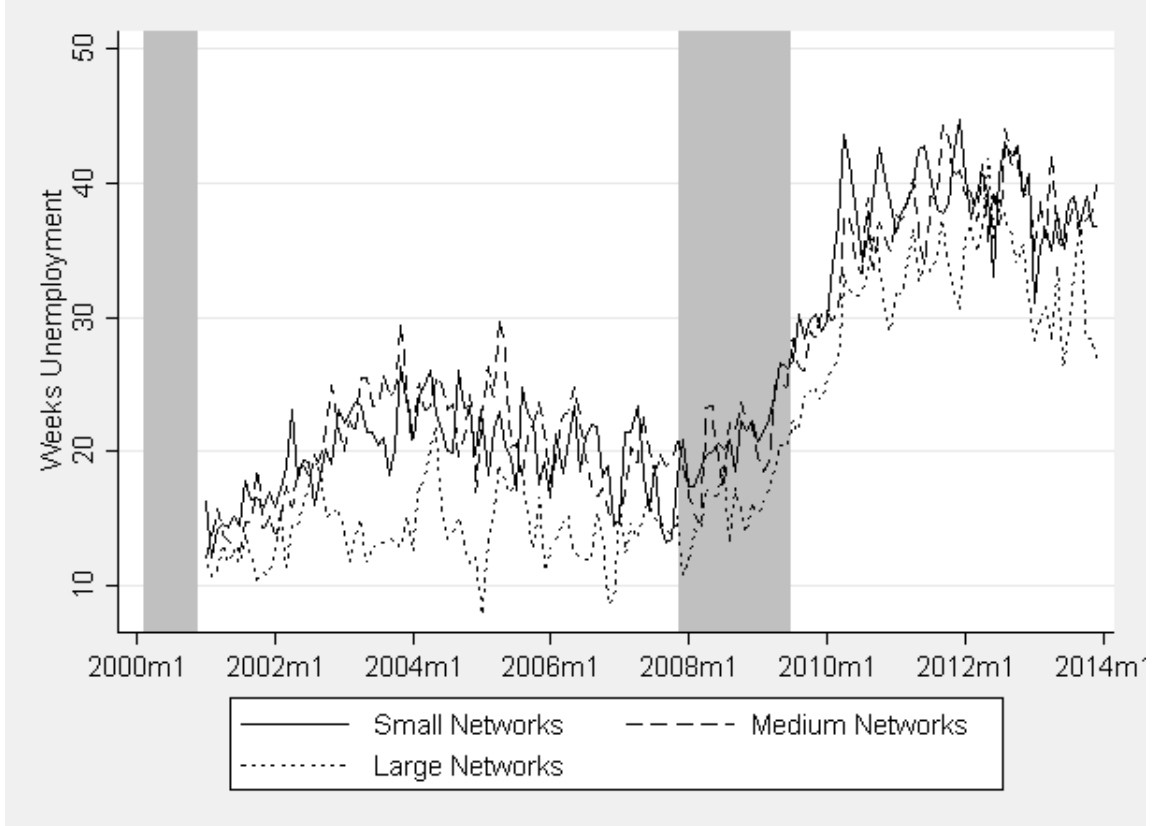

Figure 3: Unemployment Duration Monthly Trend for Immigrants across Large, Medium and Small Networks over 2000 - 2013 12 


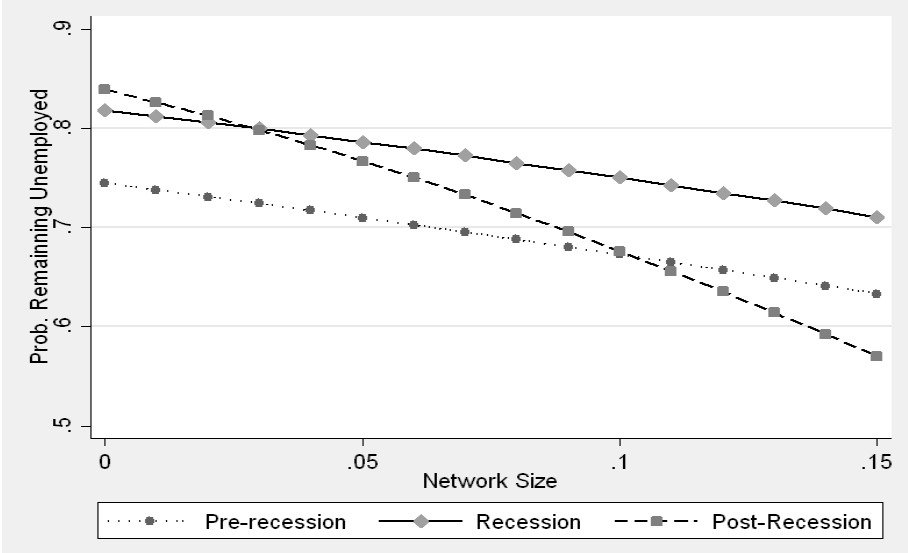

Figure 4: Predicted Risk for 1-4 Weeks of Unemployment

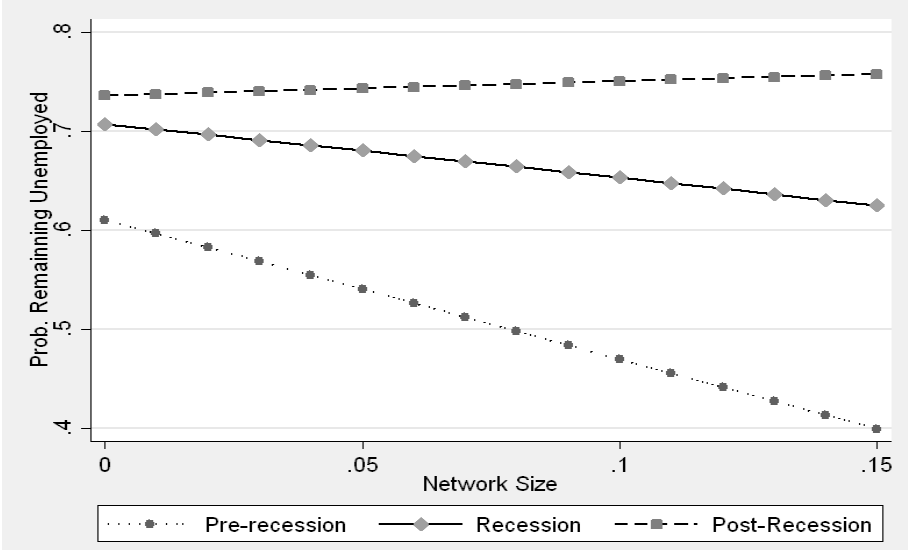

Figure 5: Predicted Risk for 27-52 Weeks of Unemployment 
Table 1: Descriptive Statistics. Mean values selected variables

\begin{tabular}{|c|c|c|c|c|}
\hline & All Migrants & $\begin{array}{r}\text { Pre Recession } \\
\text { All Migrants }\end{array}$ & $\begin{array}{r}\text { Recession } \\
\text { All Migrants }\end{array}$ & $\begin{array}{r}\text { Post Recession } \\
\text { All Migrants }\end{array}$ \\
\hline U. Duration Wks & 26.62 & 18.22 & 19.36 & 35.05 \\
\hline Netwrk Country of Birth: CPS & $4.2 \%$ & $4.1 \%$ & $4.7 \%$ & $4.1 \%$ \\
\hline Netwrk Country of Birth: ACS & $4.2 \%$ & $4.3 \%$ & $4.5 \%$ & $4.0 \%$ \\
\hline Netwrk Country of Birth: Census 90 & $2.5 \%$ & $2.5 \%$ & $2.7 \%$ & $2.5 \%$ \\
\hline U. Insurance Weeks & 58.77 & 30.67 & 46.15 & 83.84 \\
\hline Emp. Share by Skill & $64.7 \%$ & $66.6 \%$ & $64.7 \%$ & $63.3 \%$ \\
\hline Share of Recent Migrants & $14.1 \%$ & $4.9 \%$ & $17.0 \%$ & $20.4 \%$ \\
\hline US Citizen & $35.5 \%$ & $31.4 \%$ & $32.2 \%$ & $39.6 \%$ \\
\hline$\%$ Head of Household & $48.5 \%$ & $47.7 \%$ & $48.9 \%$ & $49.0 \%$ \\
\hline$\%$ Spouse & $27.3 \%$ & $27.6 \%$ & $27.2 \%$ & $27.1 \%$ \\
\hline Married & $59.7 \%$ & $59.2 \%$ & $61.3 \%$ & $59.7 \%$ \\
\hline Age & 39.59 & 38.23 & 39.01 & 40.79 \\
\hline Women & $45.8 \%$ & $47.5 \%$ & $42.6 \%$ & $45.3 \%$ \\
\hline HS Graduate+S Coll & $44.0 \%$ & $41.1 \%$ & $43.2 \%$ & $46.4 \%$ \\
\hline College + Grad & $20.7 \%$ & $20.2 \%$ & $18.9 \%$ & $21.5 \%$ \\
\hline HH Size & 3.86 & 3.83 & 3.86 & 3.87 \\
\hline \# Children & 1.17 & 1.18 & 1.17 & 1.15 \\
\hline \%White & $15.8 \%$ & $16.4 \%$ & $15.6 \%$ & $15.4 \%$ \\
\hline$\%$ Own a house & $42.8 \%$ & $41.1 \%$ & $42.6 \%$ & $44.1 \%$ \\
\hline Full Everify & $11.9 \%$ & $1.3 \%$ & $17.6 \%$ & $18.5 \%$ \\
\hline Partial Everify & $2.4 \%$ & $0.0 \%$ & $2.1 \%$ & $4.3 \%$ \\
\hline Like Everify & $8.9 \%$ & $0.7 \%$ & $12.6 \%$ & $14.3 \%$ \\
\hline Lives Metro Area & $92.3 \%$ & $95.9 \%$ & $92.9 \%$ & $89.4 \%$ \\
\hline
\end{tabular}


Table 2: Unemployment Duration: GH - ML Estimates

\begin{tabular}{|c|c|c|c|c|c|c|}
\hline & (1) & $(2)$ & $(3)$ & $(4)$ & $(5)$ & $(6)$ \\
\hline Network & $\begin{array}{c}-2.120^{* * *} \\
(0.184)\end{array}$ & $\begin{array}{c}-3.148^{* * *} \\
(0.254)\end{array}$ & $\begin{array}{c}-2.976^{* * *} \\
(0.342)\end{array}$ & $\begin{array}{c}-3.150^{* * *} \\
(0.561)\end{array}$ & $\begin{array}{c}-3.172^{* * *} \\
(0.588)\end{array}$ & $\begin{array}{c}-2.808^{* * *} \\
(0.590)\end{array}$ \\
\hline Network*Recession & & & $\begin{array}{c}0.267 \\
(0.765)\end{array}$ & $\begin{array}{l}0.0555 \\
(0.991)\end{array}$ & $\begin{array}{c}0.47 \\
(1.028)\end{array}$ & $\begin{array}{c}0.488 \\
(0.983)\end{array}$ \\
\hline Network*Post Recession & & & $\begin{array}{l}-0.514 \\
(0.503)\end{array}$ & $\begin{array}{l}-0.525 \\
(0.618)\end{array}$ & $\begin{array}{r}-0.0397 \\
(0.650)\end{array}$ & $\begin{array}{l}-0.275 \\
(0.635)\end{array}$ \\
\hline Recession & $\begin{array}{c}0.394^{* * *} \\
(0.035)\end{array}$ & $\begin{array}{c}0.522^{* * *} \\
(0.063)\end{array}$ & $\begin{array}{c}0.509^{* * *} \\
(0.077)\end{array}$ & $\begin{array}{c}0.595^{* * *} \\
(0.091)\end{array}$ & $\begin{array}{c}0.512^{* * *} \\
(0.091)\end{array}$ & $\begin{array}{c}0.411^{* * *} \\
(0.093)\end{array}$ \\
\hline Post Recession & $\begin{array}{c}0.287^{* * *} \\
(0.020)\end{array}$ & $\begin{array}{c}0.721^{* * *} \\
(0.064)\end{array}$ & $\begin{array}{c}0.751^{* * *} \\
(0.076)\end{array}$ & $\begin{array}{c}0.871^{* * *} \\
(0.078)\end{array}$ & $\begin{array}{c}0.761^{* * *} \\
(0.072)\end{array}$ & $\begin{array}{c}0.501^{* * *} \\
(0.113)\end{array}$ \\
\hline $\begin{array}{l}\text { Household head } \\
\text { or spouse }\end{array}$ & & & & $\begin{array}{l}0.0584 \\
(0.050)\end{array}$ & $\begin{array}{l}0.0467 \\
(0.051)\end{array}$ & $\begin{array}{c}0.046 \\
(0.049)\end{array}$ \\
\hline Married & & & & $\begin{array}{l}0.0297 \\
(0.038)\end{array}$ & $\begin{array}{l}0.0388 \\
(0.039)\end{array}$ & $\begin{array}{l}0.0367 \\
(0.038)\end{array}$ \\
\hline Age & & & & $\begin{array}{c}-0.0165^{* * *} \\
(0.005)\end{array}$ & $\begin{array}{c}-0.0147^{* * *} \\
(0.005)\end{array}$ & $\begin{array}{r}-0.0126 \\
(0.010)\end{array}$ \\
\hline Age sq/100 & & & & $\begin{array}{c}0.0500^{* * *} \\
(0.007)\end{array}$ & $\begin{array}{c}0.0465^{* * *} \\
(0.007)\end{array}$ & $\begin{array}{c}0.0434^{* * *} \\
(0.012)\end{array}$ \\
\hline Women & & & & $\begin{array}{c}0.210^{* * *} \\
(0.036)\end{array}$ & $\begin{array}{c}0.223^{* * *} \\
(0.037)\end{array}$ & $\begin{array}{c}0.217^{* * *} \\
(0.036)\end{array}$ \\
\hline $\begin{array}{l}\text { HS education } \\
\text { \& Some College }\end{array}$ & & & & $\begin{array}{c}0.141^{* * *} \\
(0.038)\end{array}$ & $\begin{array}{c}0.105^{* * *} \\
(0.039)\end{array}$ & $\begin{array}{c}0.284^{* * *} \\
(0.075)\end{array}$ \\
\hline College or Grad School & & & & $\begin{array}{c}0.189^{* * * *} \\
(0.048)\end{array}$ & $\begin{array}{c}0.133^{* * *} \\
(0.051)\end{array}$ & $\begin{array}{c}0.432^{* * *} \\
(0.116)\end{array}$ \\
\hline Household Size & & & & $\begin{array}{l}0.0173 \\
(0.014)\end{array}$ & $\begin{array}{l}0.0214 \\
(0.015)\end{array}$ & $\begin{array}{l}0.0206 \\
(0.015)\end{array}$ \\
\hline Number Children & & & & $\begin{array}{l}-0.019 \\
(0.019)\end{array}$ & $\begin{array}{r}-0.0191 \\
(0.020)\end{array}$ & $\begin{array}{r}-0.0195 \\
(0.020)\end{array}$ \\
\hline White & & & & $\begin{array}{c}0.00945 \\
(0.047)\end{array}$ & $\begin{array}{l}0.0139 \\
(0.049)\end{array}$ & $\begin{array}{l}0.0165 \\
(0.047)\end{array}$ \\
\hline House Owner & & & & $\begin{array}{l}0.0241 \\
(0.035)\end{array}$ & $\begin{array}{r}-0.0327 \\
(0.037)\end{array}$ & $\begin{array}{r}-0.0296 \\
(0.036)\end{array}$ \\
\hline $\begin{array}{l}\text { Recent Migrant } \\
\text { (10 years or less) }\end{array}$ & & & & & $\begin{array}{l}0.0833 \\
(0.056)\end{array}$ & $\begin{array}{l}0.0874 \\
(0.055)\end{array}$ \\
\hline US Citizen & & & & & $\begin{array}{c}0.298^{* * *} \\
(0.043)\end{array}$ & $\begin{array}{c}0.290^{* * *} \\
(0.043)\end{array}$ \\
\hline Partial Everify & & & & & $\begin{array}{c}0.342^{* * *} \\
(0.087)\end{array}$ & $\begin{array}{c}0.331^{* * *} \\
(0.084)\end{array}$ \\
\hline Full Everify & & & & & $\begin{array}{c}0.784^{* * *} \\
(0.192)\end{array}$ & $\begin{array}{c}0.775^{* * *} \\
(0.186)\end{array}$ \\
\hline Similar to Everify Policy & & & & & $\begin{array}{r}-0.0333 \\
(0.097)\end{array}$ & $\begin{array}{c}-0.00938 \\
(0.094)\end{array}$ \\
\hline $\begin{array}{l}\ln \text { (Unemployment weeks } \\
\text { benefits) }\end{array}$ & & & & & & $\begin{array}{c}0.188^{* * *} \\
(0.065)\end{array}$ \\
\hline Employment share by & & & & & & $-1.208 * * *$ \\
\hline
\end{tabular}


education level

Time Dependence

5-8 Weeks unemp

9-12 Weeks unemp

13-26 Weeks unemp

27-52 Weeks unemp

\begin{tabular}{ccccc}
$0.953^{* * *}$ & $0.967^{* * *}$ & $1.228^{* * *}$ & $1.278^{* * *}$ & $1.217^{* * *}$ \\
$(0.146)$ & $(0.152)$ & $(0.182)$ & $(0.190)$ & $(0.178)$ \\
$0.848^{* * *}$ & $0.859^{* * *}$ & $1.119^{* * *}$ & $1.188^{* * *}$ & $1.108^{* * *}$ \\
$(0.137)$ & $(0.142)$ & $(0.200)$ & $(0.215)$ & $(0.196)$ \\
$-0.628^{* * *}$ & $-0.631^{* * *}$ & $-0.865^{* * *}$ & $-0.899^{* * *}$ & $-0.883^{* * *}$ \\
$(0.045)$ & $(0.046)$ & $(0.074)$ & $(0.077)$ & $(0.075)$ \\
$-0.210^{* * *}$ & $-0.210^{* * *}$ & $-0.450^{* * *}$ & $-0.475^{* * *}$ & $-0.467^{* * *}$ \\
$(0.053)$ & $(0.053)$ & $(0.089)$ & $(0.091)$ & $(0.088)$ \\
$-1.367^{* * *}$ & $-1.376^{* * *}$ & $-1.869^{* * *}$ & $-1.944^{* * *}$ & $-1.897^{* * *}$ \\
$(0.080)$ & $(0.083)$ & $(0.134)$ & $(0.137)$ & $(0.136)$ \\
$1.045^{* * *}$ & $1.051^{* * *}$ & $1.180^{* * *}$ & $1.195^{* * *}$ & $1.178^{* * *}$ \\
$(0.041)$ & $(0.043)$ & $(0.035)$ & $(0.033)$ & $(0.035)$ \\
\hline 125778 & 125778 & 125778 & 125778 & 125778 \\
\hline
\end{tabular}


Table 3: Duration and Duration Dependence and Networks: GH-ML model

\begin{tabular}{|c|c|c|c|}
\hline & (1) & $(2)$ & (3) \\
\hline Network & $\begin{array}{c}-3.670^{* * *} \\
(1.087)\end{array}$ & $\begin{array}{c}-3.846^{* * *} \\
(0.926)\end{array}$ & $\begin{array}{c}-3.639 * * * \\
(1.085)\end{array}$ \\
\hline Network*Recession & $\begin{array}{c}-0.550 \\
(1.670)\end{array}$ & $\begin{array}{c}-0.385 \\
(1.354)\end{array}$ & $\begin{array}{r}-0.493 \\
(1.671)\end{array}$ \\
\hline Network*Post Recession & $\begin{array}{c}-5.887^{* * *} \\
(1.177)\end{array}$ & $\begin{array}{c}-4.813^{* * * *} \\
(1.024)\end{array}$ & $\begin{array}{c}-5.890 * * * \\
(1.191)\end{array}$ \\
\hline Net*(5-8weeks) & $\begin{array}{c}-2.793 \\
(2.921)\end{array}$ & & \\
\hline Net*(9 -12weeks) & $\begin{array}{c}3.225 \\
(3.490)\end{array}$ & & \\
\hline Net*(13-26 weeks) & $\begin{array}{c}2.481^{*} \\
(1.337)\end{array}$ & & \\
\hline Net*(27-52 weeks) & $\begin{array}{c}-2.366 \\
(1.564)\end{array}$ & & \\
\hline Net*(52-104 weeks) & $\begin{array}{c}0.697 \\
(2.339)\end{array}$ & & \\
\hline Net_recess*(5-8weeks) & $\begin{array}{c}1.133 \\
(4.791)\end{array}$ & & \\
\hline Net_recess*(9 -12weeks) & $\begin{array}{c}-1.186 \\
(5.462)\end{array}$ & & \\
\hline Net_recess*(13-26 weeks) & $\begin{array}{c}0.128 \\
(2.165)\end{array}$ & & \\
\hline Net_recess*(27-52 weeks) & $\begin{array}{c}3.997 \\
(2.964)\end{array}$ & & \\
\hline Net_recess*(52-104 weeks) & $\begin{array}{c}1.081 \\
(3.526)\end{array}$ & & \\
\hline Net_postrecess* ${ }^{*}$ (5-8weeks) & $\begin{array}{r}15.36 \\
(11.412)\end{array}$ & & \\
\hline Net_postrecess*(9 -12weeks) & $\begin{array}{c}2.46 \\
(4.909)\end{array}$ & & \\
\hline Net_postrecess*(13-26 weeks) & $\begin{array}{c}1.115 \\
(1.493)\end{array}$ & & \\
\hline Net_postrecess*(27-52 weeks) & $\begin{array}{c}12.73^{* * *} \\
(2.275)\end{array}$ & & \\
\hline Net_postrecess*(52-104 weeks) & $\begin{array}{c}8.623^{* * *} \\
(2.268)\end{array}$ & & \\
\hline Net*(9-26weeks) & & $\begin{array}{c}2.744^{* *} \\
(1.138)\end{array}$ & \\
\hline $\operatorname{Net}^{*}(27+$ weeks $)$ & & $\begin{array}{c}-1.277 \\
(1.358)\end{array}$ & \\
\hline Net_recess*(9-26weeks) & & $\begin{array}{l}-0.0601 \\
(1.850)\end{array}$ & \\
\hline Net_recess* $(27+$ weeks $)$ & & $\begin{array}{c}3.056 \\
(2.253)\end{array}$ & \\
\hline Net_postrecess*(9-26weeks) & & 0.22 & \\
\hline
\end{tabular}




\begin{tabular}{|c|c|c|c|}
\hline Net_postrecess*(27+ weeks) & & $\begin{array}{c}(1.298) \\
9.925^{* * *} \\
(1.390)\end{array}$ & \\
\hline Net*(5-12weeks) & & & $\begin{array}{c}-0.433 \\
(2.075)\end{array}$ \\
\hline Net*(13wks -52weeks) & & & $\begin{array}{c}1.038 \\
(1.146)\end{array}$ \\
\hline Net*(53wks +$)$ & & & $\begin{array}{c}0.744 \\
(2.359)\end{array}$ \\
\hline Net_recess*(5-12weeks) & & & $\begin{array}{c}0.375 \\
(3.399)\end{array}$ \\
\hline Net_recess*(13wks -52 week) & & & $\begin{array}{c}1.343 \\
(1.930)\end{array}$ \\
\hline Net_recess*(53+ weeks $)$ & & & $\begin{array}{c}1.08 \\
(3.525)\end{array}$ \\
\hline Net_postrecess*(5-12weeks) & & & $\begin{array}{c}8.442^{*} \\
(4.353)\end{array}$ \\
\hline Net_postrecess*(13wks -52 weeks) & & & $\begin{array}{c}4.536^{* * *} \\
(1.291)\end{array}$ \\
\hline Net_postrecess*(53+ weeks) & & & $\begin{array}{c}8.558^{* * *} \\
(2.270)\end{array}$ \\
\hline Time Dependence & & & \\
\hline 5-8 wks unemp & $\begin{array}{c}1.275^{* * *} \\
(0.276)\end{array}$ & $\begin{array}{c}1.261^{* * *} \\
(0.194)\end{array}$ & $\begin{array}{c}1.160^{* * *} \\
(0.204)\end{array}$ \\
\hline 9-12 wks unemp & $\begin{array}{c}0.936^{* * *} \\
(0.226)\end{array}$ & $\begin{array}{c}0.948^{* * *} \\
(0.191)\end{array}$ & $\begin{array}{c}1.083^{* * *} \\
(0.272)\end{array}$ \\
\hline 13-26 wks unemp & $\begin{array}{c}-1.030^{* * *} \\
(0.103)\end{array}$ & $\begin{array}{c}-1.013^{* * *} \\
(0.098)\end{array}$ & $\begin{array}{c}-1.039^{* * *} \\
(0.103)\end{array}$ \\
\hline 27-52 wks unemp & $\begin{array}{c}-0.654^{* * *} \\
(0.120)\end{array}$ & $\begin{array}{c}-0.644^{* * *} \\
(0.114)\end{array}$ & $\begin{array}{c}-0.622^{* * *} \\
(0.113)\end{array}$ \\
\hline 53-104 wks unemp & $\begin{array}{c}-2.185^{* * *} \\
(0.173)\end{array}$ & $\begin{array}{c}-2.137^{* * *} \\
(0.165)\end{array}$ & $\begin{array}{c}-2.191^{* * *} \\
(0.180)\end{array}$ \\
\hline alpha & $1.189^{* * *}$ & $1.177^{* * *}$ & $1.189^{* * *}$ \\
\hline _cons & $(0.036)$ & $(0.035)$ & $(0.038)$ \\
\hline $\mathrm{N}$ & 125778 & 125778 & 125778 \\
\hline
\end{tabular}




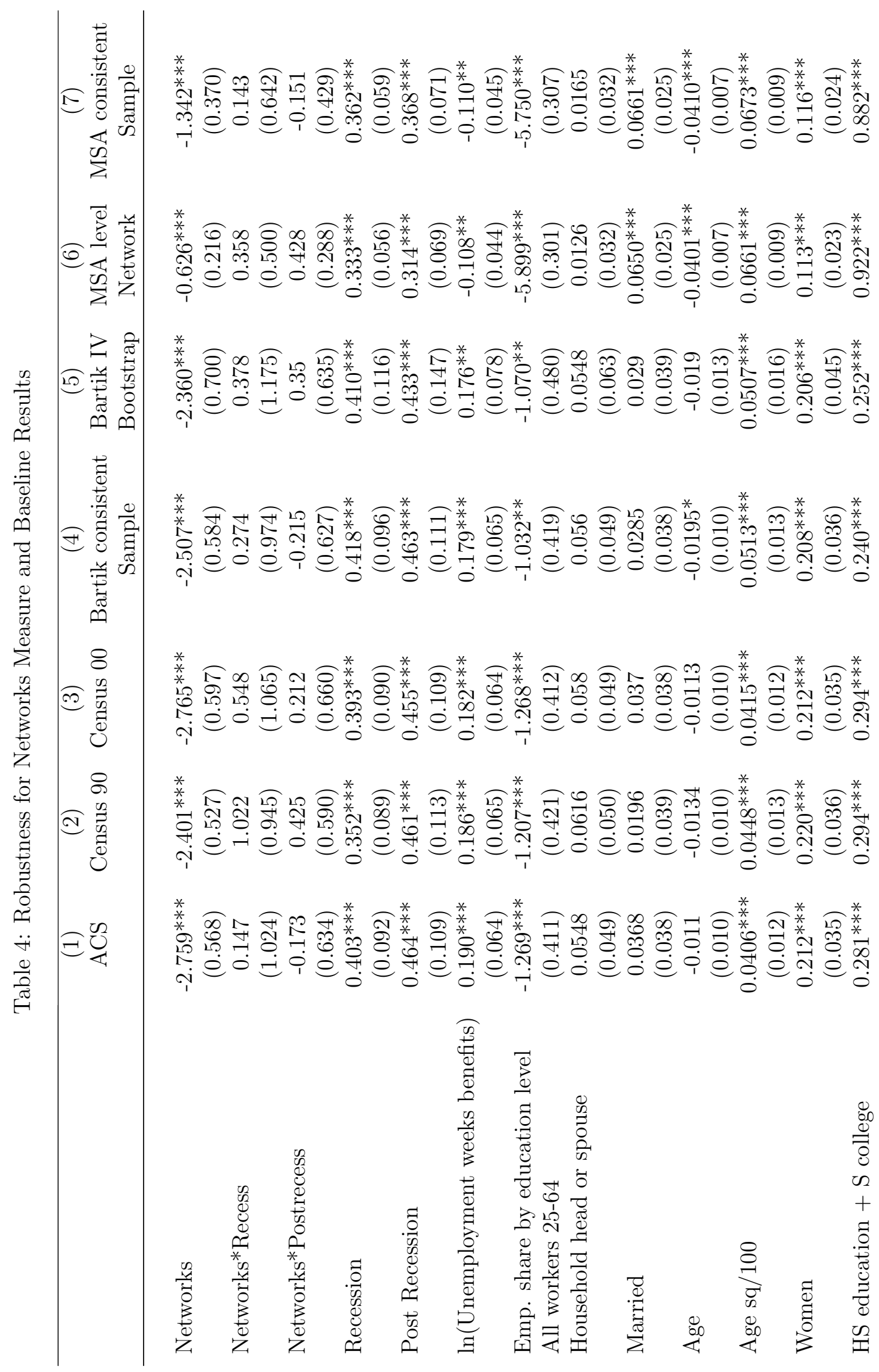




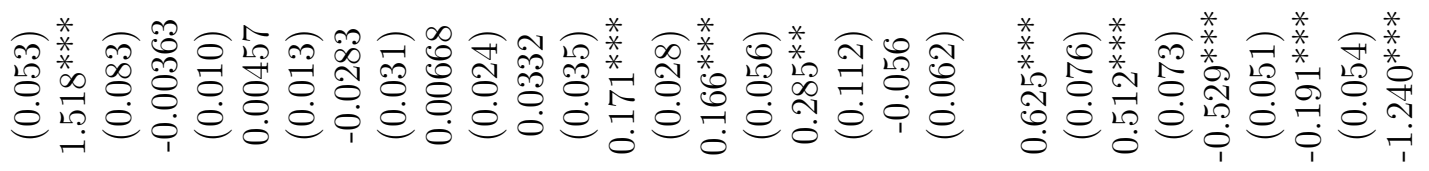

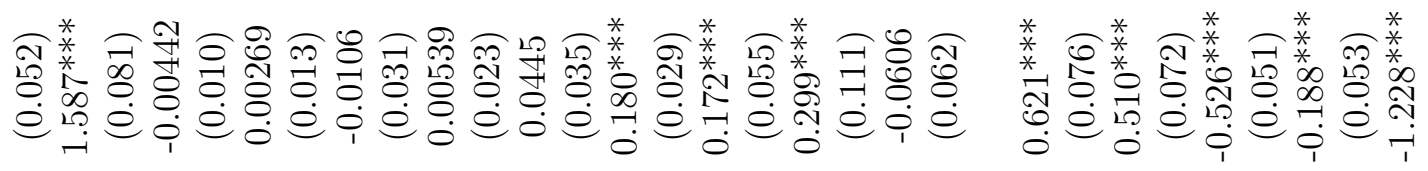

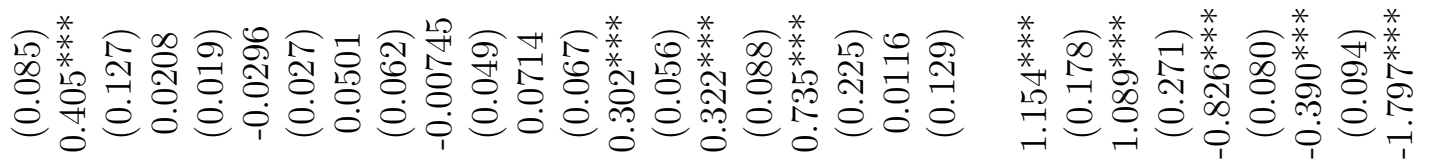

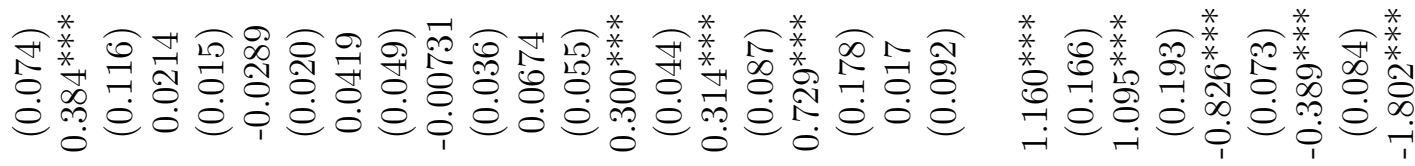

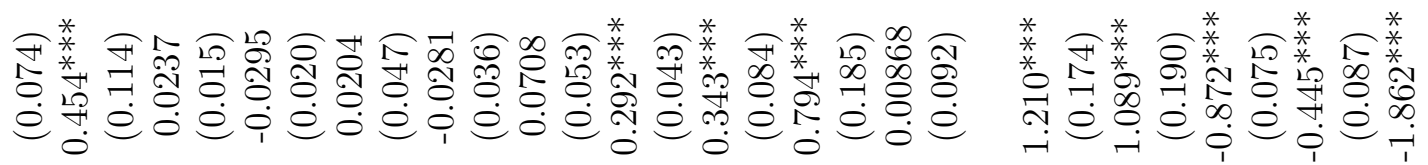

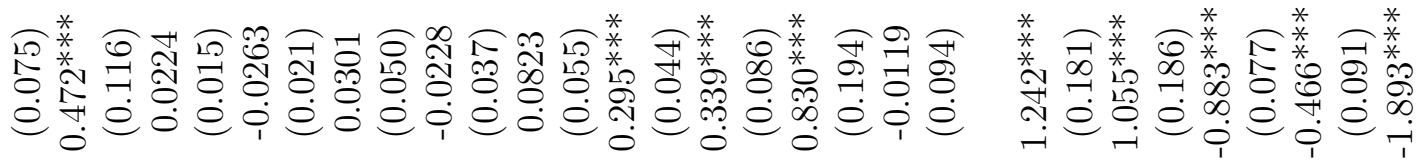

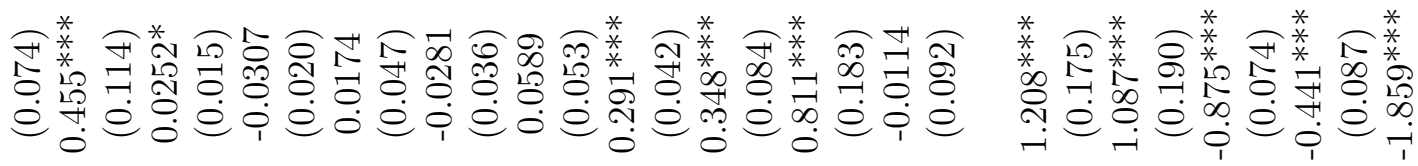

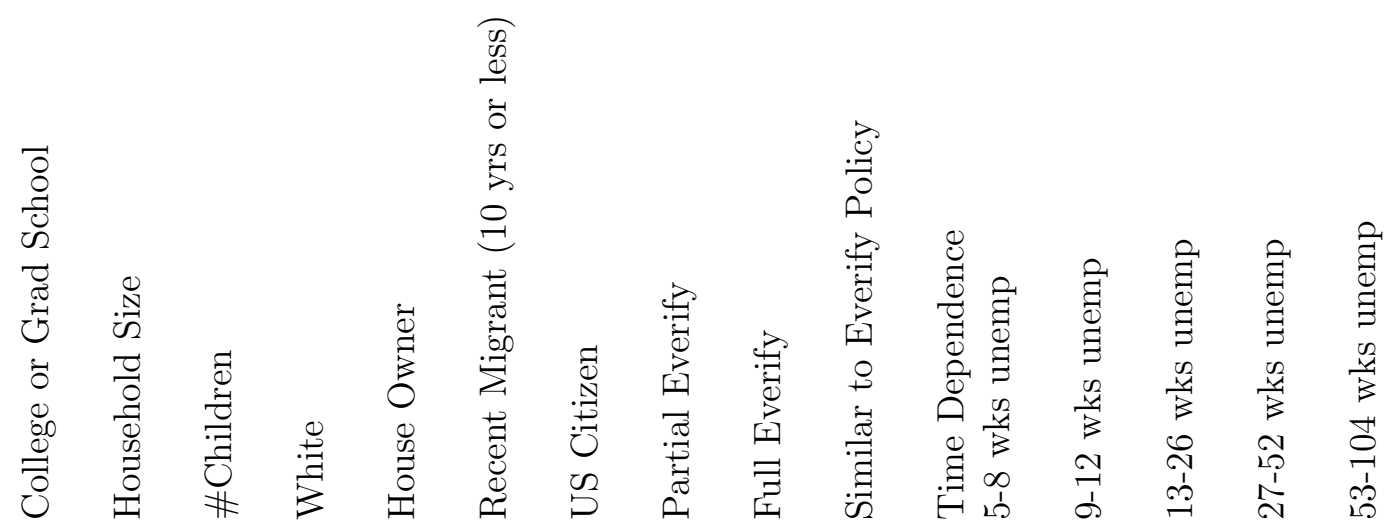




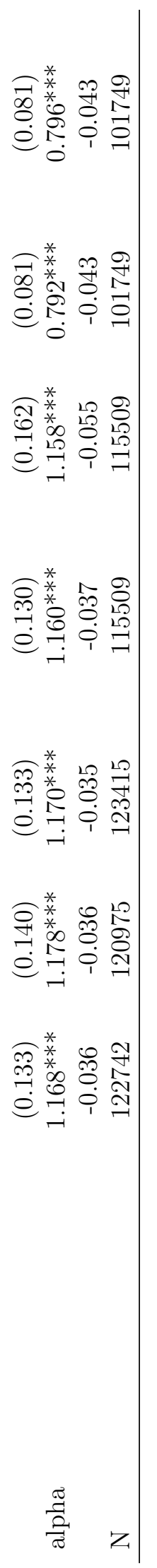


Appendix

Figure A: Distribution of the unemployment duration

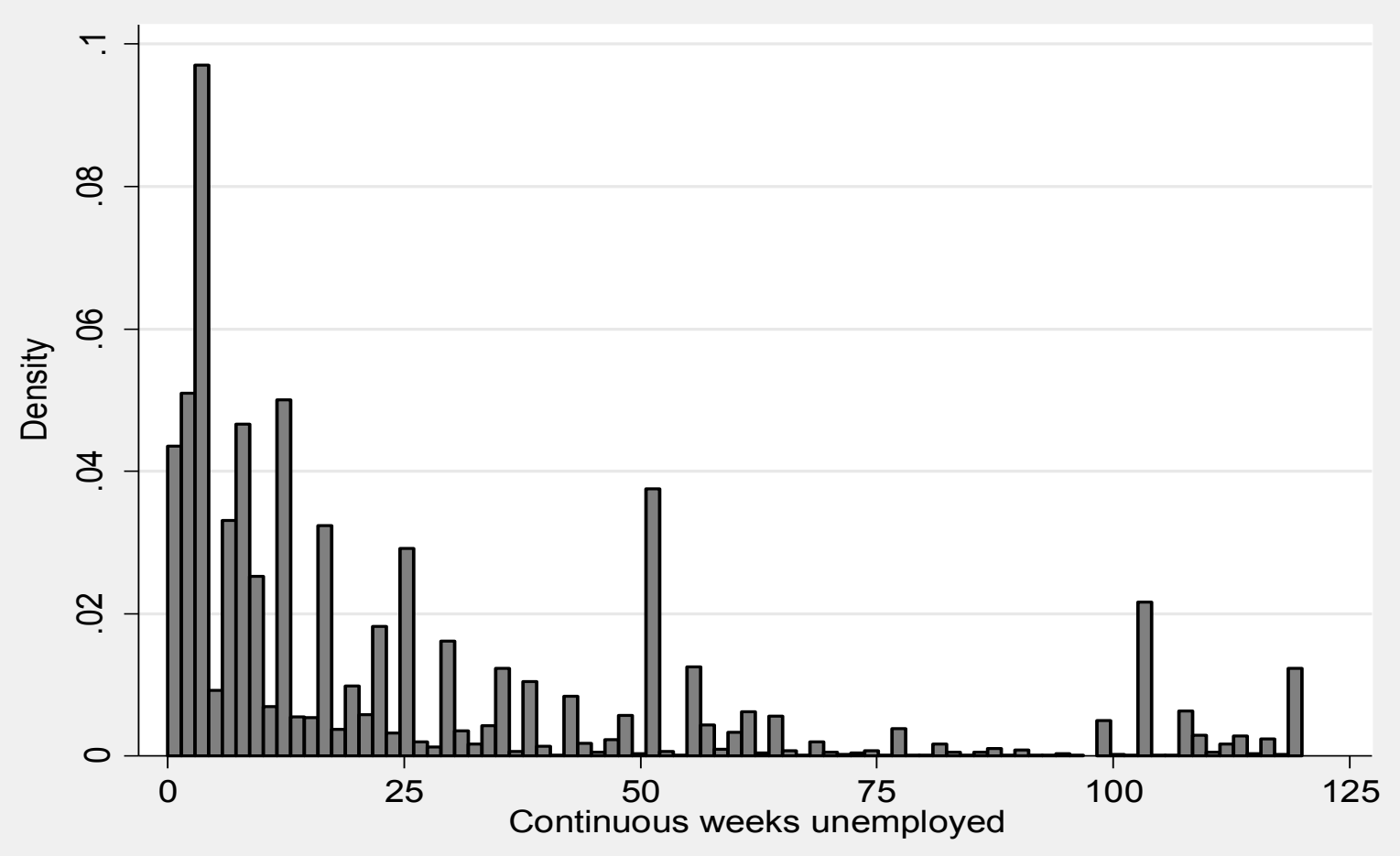


Table A: GH-ML Baseline Model

\begin{tabular}{|c|c|c|}
\hline & $\begin{array}{l}\text { Non-Mexican } \\
\text { Immigrants }\end{array}$ & $\begin{array}{c}\text { Mexican } \\
\text { Immigrants }\end{array}$ \\
\hline \multirow[t]{2}{*}{ Networks } & $-7.431^{\star \star}$ & $-20.52^{\star \star \star}$ \\
\hline & $(3.466)$ & $(4.489)$ \\
\hline \multirow[t]{2}{*}{ Networks*Recession } & -8.032 & 0.624 \\
\hline & $(7.021)$ & $(1.350)$ \\
\hline \multirow[t]{2}{*}{ Networks*Postrecess } & $10.26^{\star \star}$ & -1.300 \\
\hline & $(4.851)$ & $(1.054)$ \\
\hline \multirow[t]{2}{*}{ Recession } & $0.630 * \star \star$ & $0.545^{\star \star \star}$ \\
\hline & $(0.185)$ & $(0.187)$ \\
\hline \multirow[t]{2}{*}{ Post Recession } & $0.600^{\star \star \star}$ & $0.617^{\star \star \star}$ \\
\hline & $(0.193)$ & $(0.218)$ \\
\hline \multirow[t]{2}{*}{ In(Unemployment weeks benefits) } & $0.284^{\star *}$ & $0.288^{* \star \star}$ \\
\hline & $(0.122)$ & $(0.089)$ \\
\hline \multirow[t]{2}{*}{ Employment share by education level } & $-2.310 * \star \star$ & $2.782^{\star \star}$ \\
\hline & $(0.771)$ & $(1.088)$ \\
\hline \multirow[t]{2}{*}{ Household head or spouse } & 0.0365 & 0.0621 \\
\hline & $(0.091)$ & $(0.064)$ \\
\hline \multirow[t]{2}{*}{ Married } & $0.138^{* *}$ & -0.0578 \\
\hline & $(0.070)$ & $(0.051)$ \\
\hline \multirow[t]{2}{*}{ Age } & 0.0303 & $-0.0283^{* *}$ \\
\hline & $(0.019)$ & $(0.014)$ \\
\hline \multirow[t]{2}{*}{ Age $\wedge 2 / 100$} & -0.00123 & $0.0596^{* * *}$ \\
\hline & $(0.022)$ & $(0.019)$ \\
\hline \multirow[t]{2}{*}{ Women } & $0.118^{* *}$ & $0.339 * * *$ \\
\hline & $(0.058)$ & $(0.066)$ \\
\hline \multirow[t]{2}{*}{ HS education + S college } & $0.433^{\star * \star}$ & $-0.363^{* *}$ \\
\hline & $(0.149)$ & $(0.156)$ \\
\hline \multirow[t]{2}{*}{ College or Grad School } & $0.616^{\star \star \star}$ & $-0.478^{*}$ \\
\hline & $(0.221)$ & $(0.271)$ \\
\hline \multirow[t]{2}{*}{ Household Size } & $0.0517^{*}$ & 0.0162 \\
\hline & $(0.030)$ & $(0.019)$ \\
\hline \multirow[t]{2}{*}{ \#Children } & -0.0554 & -0.00958 \\
\hline & $(0.043)$ & $(0.024)$ \\
\hline \multirow[t]{2}{*}{ White } & 0.0138 & 0.113 \\
\hline & $(0.072)$ & $(0.204)$ \\
\hline House Owner & $-0.170 * \star$ & 0.0694 \\
\hline
\end{tabular}


Recent Migrant ( 10 yrs or less Citizen
US Partial Everify
Full Everify
Similar to Everify Policy

5-8 wks unemp
9-12 wks unemp
13-26 wks unemp
27-52 wks unemp
53-104 wks unemp
alpha
_cons

N

$\begin{array}{cc}(0.068) & (0.048) \\ 0.180 * & 0.00313 \\ (0.102) & (0.074) \\ 0.335 * \star * & 0.359 * \star \star \\ (0.067) & (0.085)\end{array}$

$0.585^{\star * *}$

$-0.176$

(0.146)

(0.139)

$2.229 * \star *$

0.158

(0.589)

(0.180)

0.127

$-0.0678$

(0.179)

(0.118)

$$
\begin{gathered}
2.973 \\
(2.507) \\
1.199 * \star \\
(0.530) \\
-1.609 * \star \star \\
(0.228) \\
-1.265^{\star \star \star} \\
(0.250) \\
-3.221 * \star \star \\
(0.337) \\
1.300 * \star \star \\
(0.030)
\end{gathered}
$$

82234 $1.111^{\star \star *}$

(0.095)

$1.059 * * *$

(0.222)

$1.151^{\text {** }}$

(0.329)

-0.672 ***

(0.099)

$-0.123$

(0.098)

$-1.285^{\star \star \star ~}$

(0.176)

43544 